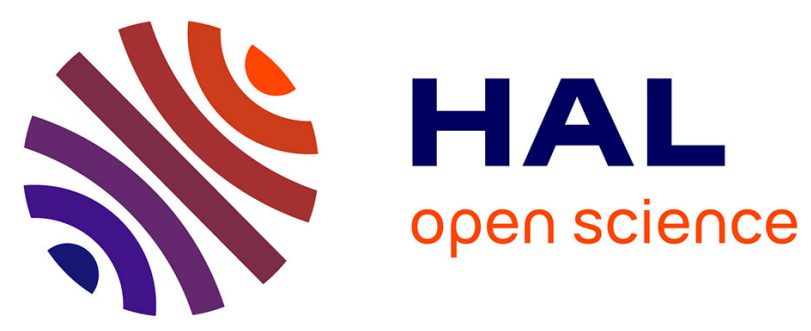

\title{
Source apportionment of carbonaceous aerosols in the vicinity of a Mediterranean industrial harbor: A coupled approach based on radiocarbon and molecular tracers
}

\author{
Lise Bonvalot, Thibaut Tuna, Yoann Fagault, Alexandre Sylvestre, Boualem
}

Mesbah, Henri Wortham, Jean-Luc Jaffrezo, Nicolas Marchand, Edouard Bard

\section{To cite this version:}

Lise Bonvalot, Thibaut Tuna, Yoann Fagault, Alexandre Sylvestre, Boualem Mesbah, et al.. Source apportionment of carbonaceous aerosols in the vicinity of a Mediterranean industrial harbor: A coupled approach based on radiocarbon and molecular tracers. Atmospheric Environment, 2019, 212, pp.250261. 10.1016/j.atmosenv.2019.04.008 . hal-02469306

\section{HAL Id: hal-02469306 https://hal.science/hal-02469306}

Submitted on 7 Feb 2020

HAL is a multi-disciplinary open access archive for the deposit and dissemination of scientific research documents, whether they are published or not. The documents may come from teaching and research institutions in France or abroad, or from public or private research centers.
L'archive ouverte pluridisciplinaire HAL, est destinée au dépôt et à la diffusion de documents scientifiques de niveau recherche, publiés ou non, émanant des établissements d'enseignement et de recherche français ou étrangers, des laboratoires publics ou privés. 


\title{
Source apportionment of carbonaceous aerosols in the vicinity of a Mediterranean industrial harbor: A coupled approach based on radiocarbon and molecular tracers
}

\author{
Lise Bonvalot ${ }^{l}$, Thibaut Tuna ${ }^{l}$, Yoann Fagault ${ }^{1}$, Alexandre Sylvestre ${ }^{2,3}$, BouAlem Mesbah ${ }^{4}$, Henri Wortham $^{2}$, Jean- $^{-}$ \\ Luc Jaffrezo ${ }^{5}$, Nicolas Marchand ${ }^{2}$ and Edouard Bard ${ }^{1}$ \\ 1 CEREGE, Aix-Marseille University, CNRS, IRD, Collège de France, Technopôle de l'Arbois, BP 80, 13545 Aix-en- \\ Provence, France \\ ${ }^{2}$ Aix Marseille Univ, CNRS, LCE, Marseille, France \\ ${ }^{3}$ Institut Ecocitoyen pour la Connaissance des Pollutions, 13270 Fos-sur-Mer, France \\ ${ }^{4}$ AirPACA, Air Quality Observatory in Provence Alpes Côte d'Azur, Marseille, France \\ 5 Univ. Grenoble Alpes, CNRS, IRD, IGE (UMR 5001), F-38000 Grenoble, France
}

\section{Abstract}

Located in the Mediterranean Basin and close to Marseilles (France), Fos-sur-Mer is situated in the vicinity of industrial harbor and agricultural lands. Its location makes it prone to mixed pollution contributions. To characterize the background pollution and identify its multiple origins, carbonaceous particles are investigated using a coupled approach based on analyses of radiocarbon, elemental to total carbon ratio (EC/TC) and various molecular tracers such as levoglucosan.

The measurements in about 30 samples collected during summer and fall/winter 2013, allow the detection of a strong seasonality of the pollution: the fall/winter $\mathrm{PM}_{2.5}$ concentration equals to three times the summer concentration and we observe a significant fluctuation of the relative contributions of fossil and nonfossil fractions ( $\mathrm{f}_{\mathrm{NF}}$ is $\approx 0.83$ for fall/winter samples and $\approx 0.59$ for summer samples).

Significant correlations between radiocarbon, levoglucosan and different methoxyphenols, allow the quantification of a major influence of biomass burning emissions during fall and winter. Biomass burning organic carbon $\left(\mathrm{OC}_{\mathrm{BB}}\right)$ and elemental carbon $\left(\mathrm{EC}_{\mathrm{BB}}\right)$ contribute to $44.5 \%$ and $8.1 \%$ of the $\mathrm{TC}$, respectively, whereas their total contribution is only $3 \%$ in summer samples.

Biogenic emission are the main sources of carbon during summer. Significant correlations with malic acid and DL glyceric acid suggest a secondary origin. These correlations are not observed for the cold season samples, suggesting a different source for $\mathrm{OC}_{\mathrm{bio}}$.

Fossil carbons $\left(\mathrm{EC}_{\mathrm{F}}\right.$ and $\left.\mathrm{OC}_{\mathrm{F}}\right)$ from vehicular, shipping and industrial sources are relatively high during summer, with a predominance of the fossil origin in elemental carbon (98\%). Nevertheless, the total fossil carbon concentration remains significant throughout the year, which is the signature of an important traffic and industrial activity during both seasons.

Overall, our study based on radiocarbon and molecular tracers illustrates the power of a coupled approach in order to identify and quantify biomass burning, biogenic, traffic and industrial sources of carbonaceous aerosols. 


\section{Introduction}

Atmospheric Particulate Matter (PM) is a challenging environmental issue as it is known to affect the climate on a regional and global scale, by reflecting, scattering and absorbing sunlight and by modifying cloud properties (Chung and Seinfeld, 2002; Penner et al., 1998; Ramanathan et al., 2001b, 2001a). Particles also have a direct and harmful effect in human health, causing respiratory and cardiopulmonary diseases (Lelieveld et al., 2015; Pope and Dockery, 2006), which can lead to an increased mortality. PM sources are either natural (biogenic emissions) or anthropogenic (heating, traffic, industry). PM can be directly emitted (Primary particles) or can be formed from the condensation of gas precursors in the atmosphere (Secondary particles). Atmospheric aerosols undergo several physical and chemical transformations (aerosol aging) which change the structure and chemical composition of particles. Their composition is complex to determine and the source apportionment remains complicated. Nevertheless, carbonaceous materials constitute an important proportion of PM in almost all cases (Fuzzi et al., 2015; Pöschl, 2005; Putaud et al., 2004, 2010). It is thus necessary to target this fraction in order to determine its sources and improve air quality.

In the last years, the Mediterranean basin PM sources have been investigated increasingly (Bozzetti et al., 2016, 2017; El Haddad et al., 2009, 2011, 2013; Salameh et al., 2015). The south of France is a region which is subjected to abrupt and intense wind episodes, which can influence the quantity and the mixing of PM. In Marseilles, among the largest harbors along the coasts of the Mediterranean Sea, different studies have shown the strong influence on aerosols of the photo-oxidation in summer and of biomass burning emissions in winter (Salameh et al., 2015).

Industrial sources are also present, which can be traced back to the Fos-Berre region in the present study. Fos-sur-Mer is a town of about 16000 inhabitants situated about $40 \mathrm{~km} \mathrm{NW}$ from Marseilles. This area is one of the most industrialized in France, being located near the region's capital city of Marseilles, which is the second main harbor in France. Moreover, the surrounding area is densely populated and close to the Fos-Berre Industrial Port Zone, (Zone Industrialo-Portuaire: ZIP). Multiple pollution sources are present in the vicinity of Fos-sur-Mer and their complex influence on atmospheric pollution is felt in and around the city of Fos-sur-Mer.

In 2008, an official study of health risks conducted on the ZIP assessed that about 9000 tons per year of $\mathrm{PM}_{2.5}$ originate from industrial emissions, while maritime and road traffic contribute about 230 and 15 tons per year, respectively (Goix et al., 2017). The regional air quality control association (AirPACA) recorded that the $\mathrm{PM}_{10}$ air quality limit (30 $\mu \mathrm{g} \mathrm{m}^{-3}$ average, per year) was exceeded for the years 2010 and 2011, illustrating the importance of background PM pollution (Dron et al., 2017).

Atmospheric emissions are complex and specific to areas such as these due to the different industrial and domestic sources present, and various measurement techniques are therefore required to improve the characterization and quantification of the sources (Crenn et al., 2017; Riffault et al., 2015).

To determine and quantify the influence of the ZIP from others (domestic and biogenic) emissions and to be able to detect sharp and singular pollution events, it is necessary to determine the atmospheric background pollution with a large data set, covering both winter and summer seasons. The analysis of radiocarbon $\left({ }^{14} \mathrm{C}\right.$, radioactive carbon isotope) in carbonaceous fractions of aerosols is an important tool for source apportionment (Bonvalot et al., 2016; Currie, 2000; Heal et al., 2011; Szidat et al., 2006, 2009). It is the best technique to distinguish and quantify fossil fuel combustion products from other non-fossil carbon sources, such as biomass burning and biogenic emissions. 
Radiocarbon is continuously and naturally produced in the upper atmosphere by the interaction between secondary neutrons from cosmic rays and nitrogen atoms from the air. The produced ${ }^{14} \mathrm{C}$ is then oxidized into ${ }^{14} \mathrm{CO}_{2}$ and mixed in the atmosphere. $\mathrm{CO}_{2}$ (and therefore ${ }^{14} \mathrm{CO}_{2}$ ) is partly taken up by vegetation during photosynthesis. Living organisms such as plants exhibit ${ }^{14} \mathrm{C} /{ }^{12} \mathrm{C}$ ratios similar to those of the atmospheric pool (in the order of $10^{-12}$ ). Consequently, biogenic emissions present the same ${ }^{14} \mathrm{C} /{ }^{12} \mathrm{C}$ ratio as the atmosphere. Emissions from biomass burning exhibit isotopic ratios close to but slightly higher than the former, due to the increase of atmospheric radiocarbon concentration during the 1950s and 1960s resulting from thermonuclear bomb tests in the atmosphere (Hua et al., 2013; Levin et al., 2010, 2013). As radiocarbon decays with a half-life of 5730 years, fossil fuels made of geological organic matter are totally depleted in ${ }^{14} \mathrm{C}$. It is thus possible to determine the nonfossil fraction $\left(\mathrm{f}_{\mathrm{NF}}\right)$ and the fossil fraction $\left(\mathrm{f}_{\mathrm{F}}\right)$ by measuring the radiocarbon in the whole carbonaceous fraction of atmospheric aerosols.

It is useful to complement ${ }^{14} \mathrm{C}$ measurements with quantifications of organic carbon and elemental carbon (OC-EC) and of the levoglucosan molecule. This compound comes from the pyrolysis of cellulose (Simoneit et al., 1999) and is mainly used as a biomass burning proxy which can be combined with ${ }^{14} \mathrm{C}$ measurements to quantify the impact of biomass burning. As biomass burning emissions are present in Marseilles during winter (El Haddad et al., 2009; Salameh et al., 2015), their contributions in Fos-sur-Mer has to be quantified. These determinations provide further information on the nature of carbonaceous compounds. The EC fraction can be associated to black carbon or soot; this fraction is a component of primary aerosols originating from combustion processes (Seinfeld and Pandis, 2006). Such measurements have been obtained for summer and winter 2012 and 2013, allowing us to quantify and apportion to sources the atmospheric aerosols of Fos-sur-Mer.

\section{Methods}

\subsection{Particulate matter sampling}

\subsubsection{Location of sampling and aims of the study}

The city Fos-sur-Mer (16 000 inhabitants) is located in the south of France, its surrounding is widely populated with about 402000 inhabitants, i.e. 311 inhabitants per km² (Sylvestre et al., 2017). The Fos-Berre Industrial Port Zone, (Zone Industrialo-Portuaire: ZIP ), has impacted the economics of the region for 40 years through various industries (oil refineries, petrochemical industry, steel metallurgy, waste management) and the associated road and maritime traffic.

Sampling was done in a Fos-sur-Mer residential zone called "les Carabins" $\left(43.45^{\circ} \mathrm{N}, 4.93^{\circ} \mathrm{E}\right)$, located adjacent to the ZIP. This sampling site is considered to be representative of the urban background of the studied region and of the inhabitants' exposure. It is by agricultural lands and a French Air Force base, to the east by the "Étang de Berre", (with a residential area and petrochemical activities), to the south by the Mediterranean Sea, (with a strong maritime traffic, but also some residential areas and petrochemical activities) and to the southwest/south by the ZIP center with its many industrial sources, petrochemical activities, steel industry and maritime traffic.

Our present work is focused on carbonaceous particles in $30 \mathrm{PM}_{2.5}$ samples from Fos-sur-Mer. The field campaign was conducted from May 2012 to August 2013. $\mathrm{PM}_{2.5}$ samples were collected daily (24h per day, starting at (h UTC) for the whole period. More specifically, of the 30 samples, 1 was sampled during the spring of 2012, 
20 were sampled during the cold season (fall/winter) of 2012-2013, and the remaining 9 were collected during summer 2013.

\subsection{Measurements and analyses}

\subsubsection{Organic markers}

Organic marker measurements were carried out by gas chromatography (GC) coupled with mass spectrometry (MS). The analytical method is described in El Haddad et al. (2009, 2013). Briefly, after extraction by Accelerated Solvent Extractor (ASE Dionex 300), a first fraction of this extract is directly analyzed using GCMS, for quantification of weakly polar compounds (alcanes, PAH, and others). A second fraction is derivatized before injection in order to analyze the most polar compounds, such as anhydrous sugars.

For this study we focus on levoglucosan, which is formed during the pyrolysis of cellulose (Simoneit et al., 1999) at temperatures higher than $300^{\circ} \mathrm{C}$ (Caseiro et al., 2009). For this reason, levoglucosan is widely used as a biomass burning tracer in apportionment studies (Dusek et al., 2017; Jordan et al., 2006; Martinsson et al., 2017; Schauer et al., 2001; Zhang et al., 2008). It is noteworthy that several studies have shown that levoglucosan may not be stable in the troposphere (Hennigan et al., 2010), leading to reduced life time (1-5 days) in the atmosphere, depending on the season and atmospheric conditions. However, the degradation rate of levoglucosan in ambient atmospheric aerosols is yet to be determined (Yttri et al., 2015).

\subsubsection{Major ions and trace elements}

The quantification of major ions $\left(\mathrm{SO}_{4}{ }^{2-}, \mathrm{NO}_{3}{ }^{-}, \mathrm{NH}^{4-}, \mathrm{Na}^{+}, \mathrm{K}^{+}, \mathrm{Mg}^{2+}\right.$ and $\left.\mathrm{Ca}^{2+}\right)$ was carried out by ion chromatography following methods described by Jaffrezo et al. (1998). Trace elements, such as calcium, aluminum, lead, copper, and others were analyzed by ICP-MS, following the method described in (Waked et al., 2014).

\subsection{3. $O C-E C$}

OC (Organic Carbon) and EC (Elemental Carbon) were quantified by thermo-optical analysis. A Sunset device (Birch and Cary, 1996), running the EUSAAR_2 method (Cavalli et al., 2010) was used to analyze $1.5 \mathrm{~cm}^{2}$ punches of the sampled filters. Total carbon (TC) was determined by calculating the sum of OC and EC measurements. Those values were also used to determine the EC/TC ratio for each sample. The EC fraction is composed of primary particles only and originates from the combustion process, whereas the OC fraction is more complex and is composed of primary and secondary particles (Gelencsér, 2004; Pöschl, 2005).

\subsection{4. ${ }^{14} \mathrm{C}$ measurements and $f_{N F}$}

Radiocarbon measurements are carried out using Aix MICADAS, a compact AMS dedicated to the measurement of ultra-small samples (Bard et al., 2015; Synal et al., 2007). It is equipped with a hybrid ion source, which can handle both solid (graphite) and gaseous $\left(\mathrm{CO}_{2}\right)$ samples. AixMICADAS and its performances are fully described elsewhere (Bard et al., 2015). For aerosol analysis, it is coupled to an elemental analyzer (Vario MicroCube, Elementar) by the Gas Interface System (GIS). The EA (Elemental Analyzer) combustion tube is filled with tungsten oxide granules and heated to $1050{ }^{\circ} \mathrm{C}$; the reduction tube is composed of copper wires and silver wool, maintained at $550{ }^{\circ} \mathrm{C}$.

A small piece of the impacted filter $\left(0.95 \mathrm{~cm}^{2}\right)$ is sufficient for ${ }^{14} \mathrm{C}$ measurements, as a carbon mass of between 10 and $100 \mu \mathrm{gC}$ is needed with the ion source in gas mode (Bonvalot et al., 2016). The small sample 
punch is wrapped in a silver boat that has previously been prebaked at $800{ }^{\circ} \mathrm{C}$ for 2 hours in order to limit organic contamination. The $\mathrm{CO}_{2}$ obtained by combustion in the EA is collected and quantified by the GIS, before being injected into the ion source for the AMS measurement.

For each filter, two measurements were performed. The carbon mass (TC) was determined by the GIS with an overall error of $4 \%$ (Bonvalot et al. 2016). This error is based on the average difference between duplicated measurements of aerosol samples. It represents the overall uncertainty, including the measurement uncertainty of the GIS itself and is linked to possible heterogeneities of the sampled filters. This $4 \%$ uncertainty is propagated to all carbon mass values from the GIS.

Radiocarbon results are based on measured ${ }^{14} \mathrm{C} /{ }^{12} \mathrm{C}$ ratios, which are corrected for fractionation using the ${ }^{13} \mathrm{C}$ ion beam analyzed on a separate Faraday cup of AixMICADAS. Corrected ${ }^{14} \mathrm{C}$ data are then expressed as $\mathrm{F}^{14} \mathrm{C}$, a normalized activity equivalent to fraction modern (Reimer et al., 2004), which does not depend on the year of measurement. The radiocarbon measurement protocol and contamination correction method are fully described in (Bonvalot et al., 2016). The contamination brought by the EA and silver boat is estimated at $\mathrm{M}_{\mathrm{C}}=1.45 \pm 0.26$ $\mu \mathrm{gC}$, with a $\mathrm{F}^{14} \mathrm{C}_{\mathrm{C}}$ of $0.73 \pm 0.11$ (confidence interval of $2 \sigma$ ). To calculate the sample mass $\left(\mathrm{M}_{\mathrm{S}}\right.$ ) and the sample modern fraction $\left(\mathrm{F}^{14} \mathrm{C}_{\mathrm{S}}\right)$, the measured values $\left(\mathrm{M}_{\mathrm{M}}\right.$ and $\left.\mathrm{F}^{14} \mathrm{C}_{\mathrm{M}}\right)$ are corrected for this contamination with the following formulas:

$$
\begin{gathered}
M_{S}=M_{M}-M_{S} \\
F^{14} C_{S}=\frac{F^{14} C_{M} \times M_{M}-F^{14} C_{C} \times M_{C}}{M_{M}-M_{C}}
\end{gathered}
$$

$\mathrm{F}^{14} \mathrm{C}_{\mathrm{S}}$ is then used to calculate the non-fossil fraction $\left(\mathrm{f}_{\mathrm{NF}}\right) . \mathrm{f}_{\mathrm{NF}}$ is the radiocarbon measurement normalized to a reference value $\left(\mathrm{f}_{\mathrm{NF}, \mathrm{ref}}\right)$, which considers the increase of atmospheric $\mathrm{F}^{14} \mathrm{C}$ resulting from the thermonuclear weapon tests of the late 1950s and early 1960s (Levin et al., 2010). According to (Levin et al., 2013), the atmospheric radiocarbon value for the end of 2012 is around $1.04 \mathrm{~F}^{14} \mathrm{C}$, which is the value chosen for calculating our non-fossil fraction:

$$
f_{N F}=\frac{F^{14} C_{\text {Sample }}}{f_{N F, \text { ref }}}
$$

\section{Results}

\subsection{PM2.5 composition}

$\mathrm{PM}_{2.5}$ concentration in the air varies significantly with the season, as illustrated in Figure 1. It was estimated by mass balance, based on chemical composition (i.e. the organic matter, elemental carbon, sulfate, nitrate and ammonium). The OM fraction was determined using the OC measurements and by assuming an OM/OC ratio of 1.2 (Aiken et al., 2008; Sylvestre et al., 2017). During the warm season, the average concentration is about 15 $\mu \mathrm{g} \cdot \mathrm{m}^{-3}\left(\mathrm{SD}=3 \mu \mathrm{g} \mathrm{m}^{-3}, \mathrm{~N}=9\right)$, which is below the French regulatory threshold $\left(25 \mu \mathrm{g} \cdot \mathrm{m}^{-3}\right.$, in average per year) but higher than the WHO recommended value $\left(10 \mu \mathrm{g} \mathrm{m}^{-3}\right)$. The mean $\mathrm{PM}_{2.5}$ for summer samples is close to that determined by (El Haddad et al., 2011) for the summer of 2008 in Marseille. For the winter, the average $\mathrm{PM}_{2,5}$ 
concentration is around $41 \mu \mathrm{g} \cdot \mathrm{m}^{-3}\left(\mathrm{SD}=14 \mu \mathrm{g} \cdot \mathrm{m}^{-3}, \mathrm{~N}=20\right)$, hence significantly greater than the regulatory threshold for warning the general public.

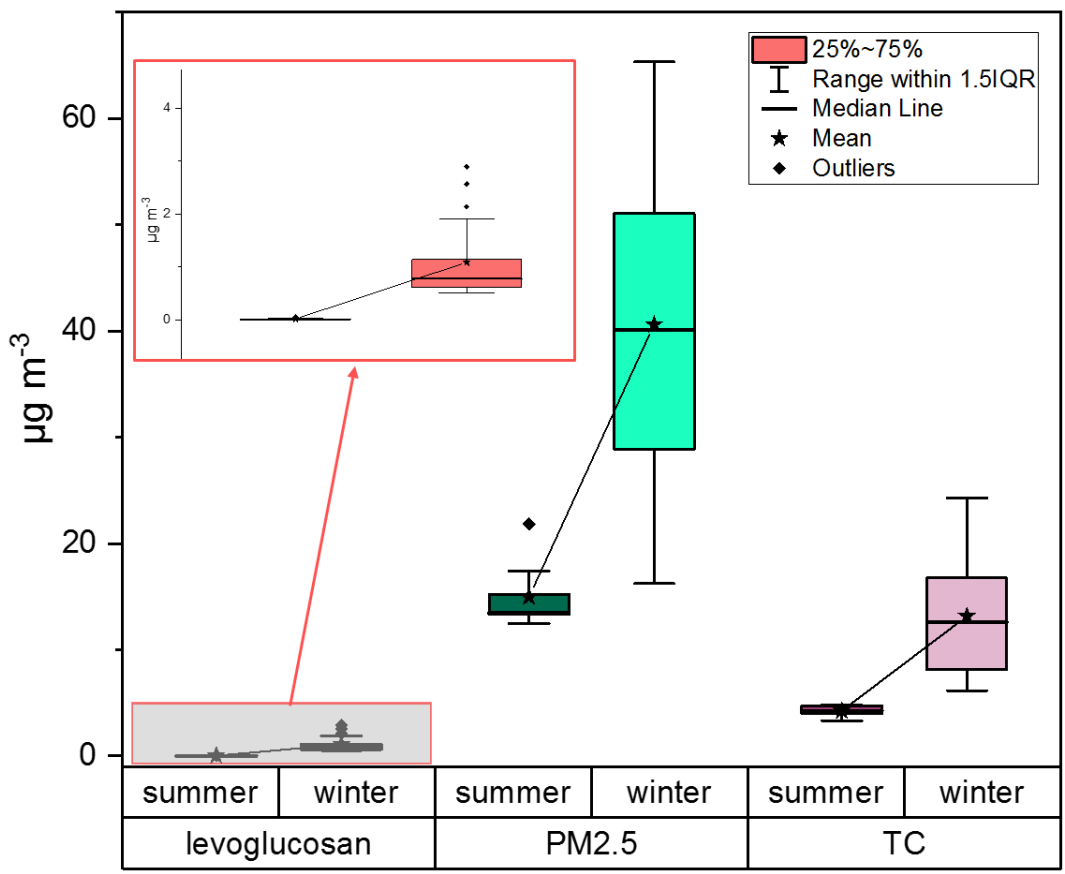

Figure 1 Box plot representation of levoglucosan, $\mathbf{P M}_{2.5}$ and TC concentrations for summer and winter

The proportion of carbon in the $\mathrm{PM}_{2.5}$ is fairly constant at about $30 \%$ throughout the year (33\% during winter and $29 \%$ during summer, Figure 1). TC amounts for the fall/winter (mean concentration $=13 \mu \mathrm{gC} \mathrm{m}{ }^{-3}, \mathrm{SD}=6$ $\mu \mathrm{gC} \mathrm{m}{ }^{-3}, \mathrm{~N}=20$ ) and the summer (mean concentration $=4 \mu \mathrm{gC} \mathrm{m}^{-3}, \mathrm{SD}=1 \mu \mathrm{gC} \mathrm{m}^{-3}, \mathrm{~N}=9$ ) are higher than those observed in the Netherlands, for a site with similar characteristics. The Dutch Caesar Observatory is located in an agricultural area close to Rotterdam which includes the largest harbor in Europe and an important industrial area. In this regional background of a relatively polluted area of the Netherlands (Dusek et al., 2017). $\mathrm{PM}_{2.5}$ compositions in Five European Mediterranean cities were investigated by (Salameh et al., 2015). Seasonality was also observed, with maximum TC concentrations in fall for Thessaloniki (Greece) and in winter for Marseilles (France) and Venice (Italy); the two other cities of Barcelona (Spain) and Genoa (Italy) differ, with maximum TC concentration in spring and no seasonality, respectively. Marseilles and Thessaloniki TC concentrations are quite close to those obtained in Fos-sur-Mer (Salameh et al., 2015).

Levoglucosan concentrations by season are represented Figure 1. During summer, levoglucosan concentrations remain low (mean concentration $=16 \mathrm{ng} \mathrm{m}^{-3}, \mathrm{SD}=11 \mathrm{ng} \mathrm{m}^{-3}, \mathrm{~N}=9$ ) and are close to summer levels described by (Puxbaum et al., 2007) for six background stations located on a transect from Hungary to the Azores, and are in the same range as concentrations measured in Marseille during summer 2008 (El Haddad et al., 2011).The impact of biomass burning during summer can thus be considered as very weak.

For the fall/winter samples, levels of levoglucosan are about 70 times higher than for summer (mean concentration $=1.1 \mu \mathrm{g} \mathrm{m}^{-3}, \mathrm{SD}=0.8 \mu \mathrm{g} \mathrm{m}^{-3}, \mathrm{~N}=20$ ), which is greater than all winter/summer ratios reported by (Puxbaum et al., 2007). Strong seasonal patterns were also detected in several European cities such as Oslo, Munich and Granada (Jedynska et al., 2015; Titos et al., 2017). Similar winter concentrations were obtained in 
Aveiro (Portugal) in 2002-2003 and 2003-2004. Nevertheless, winter levels of levoglucosan in Fos-sur-Mer remain lower than those detected in winter in French and Swiss alpine valleys, which suffer from strong pollution periods due to biomass combustion (Bonvalot et al., 2016; Favez et al., 2009; Zotter et al., 2014). These alpine valleys are enclosed between steep slopes and are characterized by temperature inversions which limit atmospheric mixing during winter. These specific meteorological conditions are not experienced in Fos-sur-Mer.

The non-fossil fraction presents a seasonality with a $\mathrm{f}_{\mathrm{NF}}$ of 0.83 during the fall/winter and a $\mathrm{f}_{\mathrm{NF}}$ of 0.59 for the summer. A similar pattern is observed in locations with important atmospheric pollution, such as the Po Valley, Italy (Gilardoni et al., 2011), Barcelona, Spain (Minguillón et al., 2011) and Tokyo, Japan (Minoura et al., 2012). Such seasonal variation was not detected in Birmingham (UK) in 2007/2008; where the $f_{\mathrm{NF}}$ (about 0.5) remained rather constant throughout the year (Heal et al., 2011). The non-fossil fraction observed in Milan (Italy) during the winters of 2010-2011 and 2011-2012 (Bernardoni et al., 2013) is smaller than for the winter in Fos-sur-Mer. The winter values in Milan range between 0.46 and 0.62, which is close to Fos-sur-Mer summer values. In France, this seasonality is also observed in $\mathrm{PM}_{1}$ sampled in the mega city of Paris (Beekmann et al., 2015) with a $\mathrm{f}_{\mathrm{NF}}$ of $62 \%$ for summer samples and of $78 \%$ for the winter samples.

Sources of carbonaceous aerosols can be apportioned using the measured values of EC/TC, levoglucosan, $\mathrm{TC}$ and $\mathrm{f}_{\mathrm{NF}}$ based on ${ }^{14} \mathrm{C}$. These calculations are performed in two steps. The first step is carried out following the method described in (Bonvalot et al., 2016), and provides the origins of the carbonaceous fraction. The second step, based on (Salma et al., 2017), enables to go further in the attribution by distinguishing the organic carbon (OC) fraction from the elemental carbon (EC) fraction. The different fractions of the carbonaceous aerosols are represented in Figure 2:

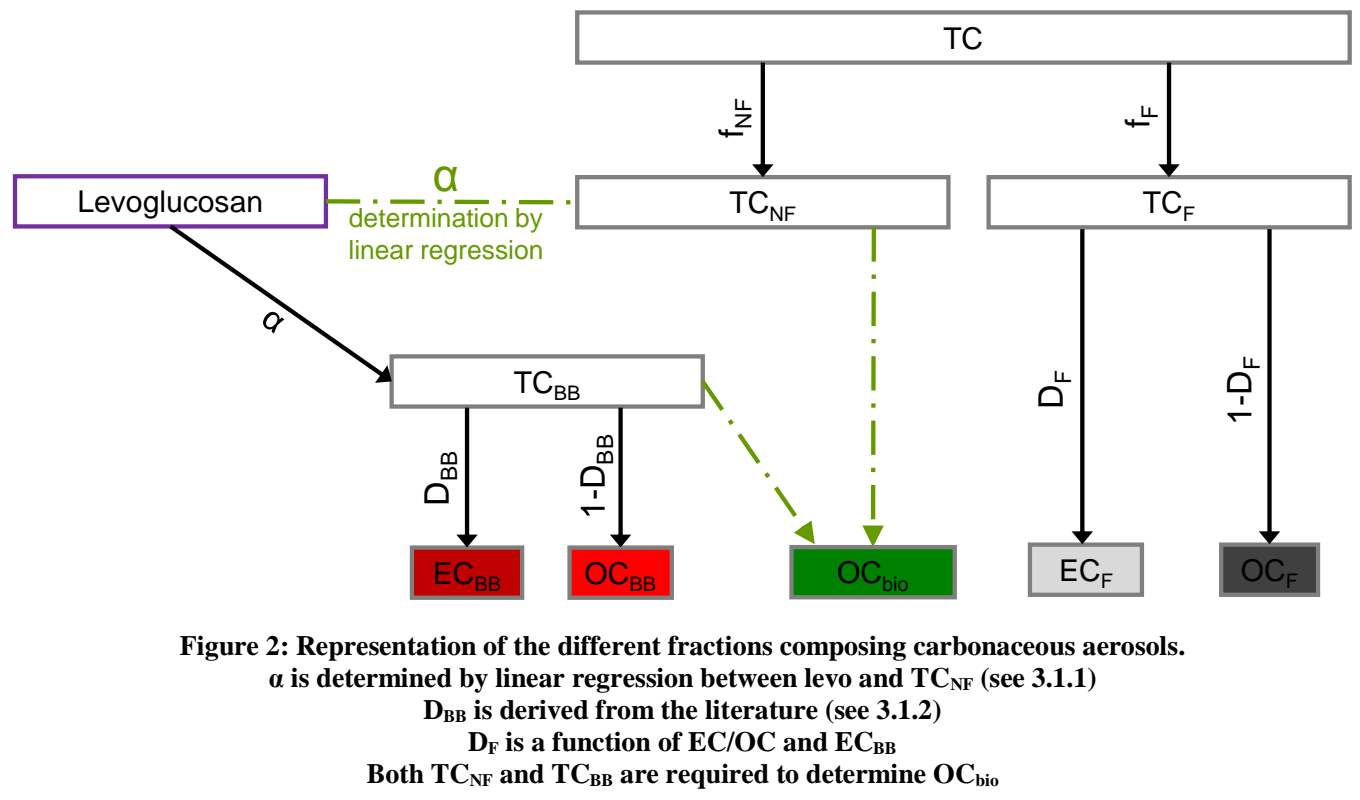

\subsubsection{Total Carbon apportionment}

First, the distinction between $\mathrm{TC}_{\mathrm{F}}$ (fossil total carbon) and $\mathrm{TC}_{\mathrm{NF}}$ (non-fossil total carbon) is made as described in equations 3 and 4 , by using the measured carbon concentration and the measured $\mathrm{f}_{\mathrm{NF}}$. The different factors in the equations are distinguished by color. Terms in purple represent experimental results on individual samples, terms in green originate from correlation with experimental data, and terms in black are calculation results. 


$$
\begin{gathered}
T C_{N F}=f_{N F} \times T C \\
T C_{F}=f_{F} \times T C=\left(1-f_{N F}\right) \times T C
\end{gathered}
$$

$\mathrm{TC}_{\mathrm{NF}}$ is predominant in all samples and can originate from two major sources: biomass burning and biogenic emissions from natural sources, such as plants and trees. Both fractions are composed of primary organic aerosols (POAs) and secondary organic aerosols (SOAs) (Hallquist et al., 2009). To distinguish the different fractions composing $\mathrm{TC}_{\mathrm{NF}}$, the fall/winter values are used as represented in Figure 3 (a).

The presence of levoglucosan provides direct evidence for the influence of biomass burning. To quantify this influence, the slope ( $\alpha$ coefficient) of the linear regression (least squares method) between $\mathrm{TC}_{\mathrm{NF}}$ concentration and levoglucosan concentration is calculated. This value represents the TC/levo ratio linked purely to the biomass burning source, i.e. $\mathrm{TC}_{\mathrm{BB}} /$ levo. The zero intercept, $\beta$, represents the biogenic emission background assumed to be constant for a given season. The schematic regression presented in Figure 3 (b) takes into account the uncertainties on $\mathrm{TC}_{\mathrm{NF}}$, which are based on ${ }^{14} \mathrm{C}$ measurements. The uncertainty on each levoglucosan concentration is estimated at around $\pm 10 \%$ ( $95 \%$ confidence factor).

For Fos-sur-Mer, we obtain a slope $\alpha$ of $6.6 \pm 1.5$, which is roughly equivalent to the values obtained for Passy (6.0 \pm 0.2$)$ and Chamonix (5.9 \pm 0.3 ), both located in the French Alps (Bonvalot et al., 2016). The $\alpha$ value is also within the $\mathrm{TC}_{\mathrm{BB}} /$ levo range (4.3 and 17.2) based on experimental studies performed by (Schmidl et al., 2008).

The zero intercept, $\beta$ coefficient, represents the average value of $\mathrm{TC}_{\text {bio }}$ during the fall/winter season, with a value of $2.5 \pm 1.3 \mu \mathrm{gC}$. The biogenic contribution is thus significant during the cold season (fall and winter) in Fos-sur-Mer. This is clearly different from $\beta$ values close to zero corresponding to negligible biogenic contribution by the vegetation reported for the French Alps Valleys in winter (Bonvalot et al., 2016).

Levoglucosan is probably the most widely used molecular tracer for biomass burning because its concentration represents a significant proportion of $\mathrm{OA}_{\mathrm{BB}}$ for fresh emissions (about 15-50\%, depending of the nature of combustion, as described by Bertrand et al, 2018). In our case, levoglucosan represents between 4 and $13 \%$ of the total OM (Organic Matter) for winter samples. However, there are other BB tracers (Simoneit, 2002) like methoxyphenols which are emitted by thermal decomposition of lignin. For example, vaniline, acetovanillone and vanillic acid can also be used as BB tracers (Bertrand et al., 2018). In the case of Fos-sur-Mer, the concentrations of these compounds is small (less than $0.03 \mu \mathrm{g} \mathrm{m}^{-3}$, each) and their sum represents less than $0.3 \%$ of winter OM. However their detection limit is small enough to make them useful complements to levoglucosan. In addition, these compounds are synthesized as primary aerosols, but their relative concentration increases with aging of the aerosols, showing that they also belong to secondary aerosols (classified as non-conventional primary compounds by Bertrand et al. 2018). This double origin makes these trace compounds particularly appealing as biomass burning tracers.

Linear regressions between $\mathrm{TC}_{\mathrm{NF}}$ and vaniline, acetovanillone or vanillic acid are all very significant (Pearson'r $=0.76$ to 0.85 , adjusted $R^{2}=0.55$ to 0.73 ). Apparent differences of the linear slopes for the three methoxyphenols (Figure 3c) may be related to their different secondary enrichments during aging of the aerosols. Figure 3 (c) also shows that the three linear regressions converge towards a similar zero intercept (3.9 to $5.0 \pm 0.7$ 
$\mu \mathrm{gC})$ which is compatible with the value found for the $\mathrm{TC}_{\mathrm{NF}}-\mathrm{levoglucosan}$ regression $(2.5 \pm 1.3 \mu \mathrm{gC})$. Overall, this confirms our average $\mathrm{TC}_{\text {bio }}$ estimation around $3 \mu \mathrm{g} \mathrm{m}^{-3}$.

a.

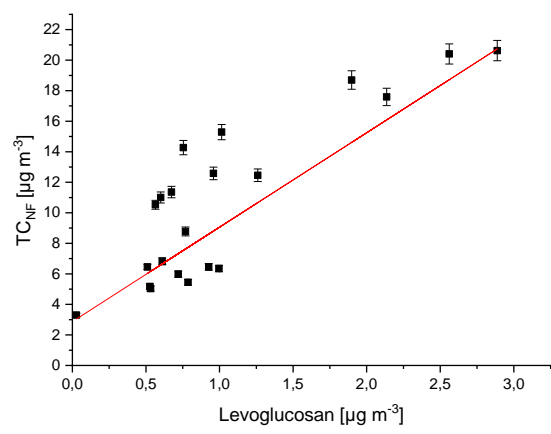

b.

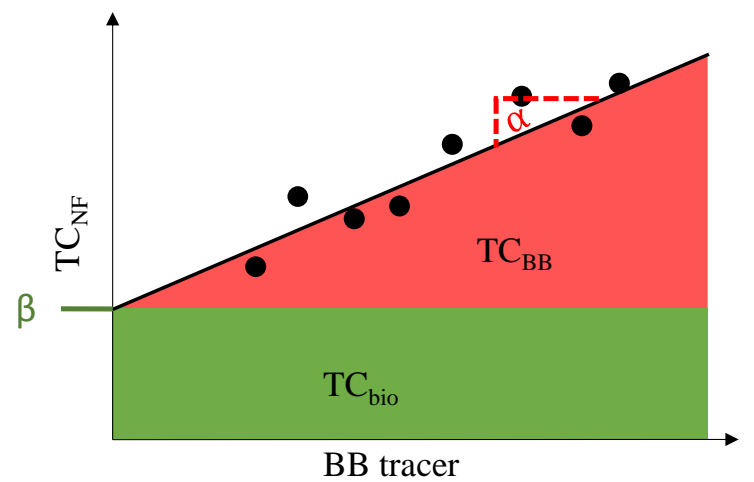

c)

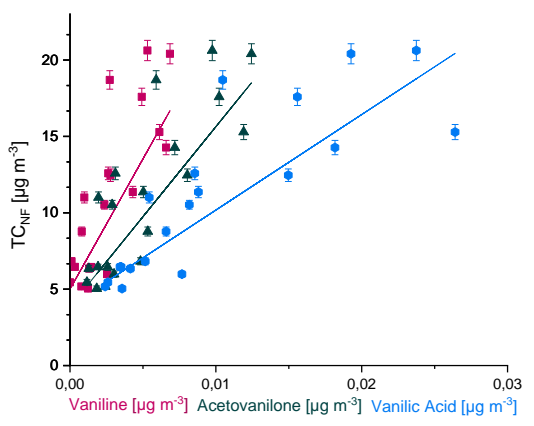

Figure 3 : (a)Linear regression of $\mathrm{TC}_{\mathrm{NF}}$ vs. levoglucosan $\mathrm{TC}_{\mathrm{NF}}=\alpha$ x lévo $+\beta$ $\alpha=6.6 \pm 1.5$ $\beta=2.5 \pm 1.3$

Pearson's $r=0.714$, Adjusted $R^{2}=0.482$

(b) Representation of $\alpha$ and $\beta$ determination

(c) Linear regression of $\mathrm{TC}_{\mathrm{NF}}$ vs.three other $\mathrm{BB}$ tracers (vaniline, acetovanilone, vanillic acid)

$$
\mathbf{T C}_{\mathrm{NF}}=\mathrm{A} \times \text { tracer }_{\mathrm{BB}}+\mathrm{B}
$$

$A_{\text {vaniline }}=1703.4 \pm 347.4 B_{\text {vaniline }}=5.0 \pm 0.7$ Pearson's $r=0.756$, Adjusted $R^{2}=0.548$

$A_{\text {acetovanilone }}=1178.5 \pm 206.6 B_{\text {acetovanilone }}=3.9 \pm 0.8$ Pearson's $r=0.802$, Adjusted $R^{2}=0.624$

$A_{\text {vanilic acid }}=625.5 \pm 90.7 B_{\text {vanilic acid }}=3.9 \pm 0.7$ Pearson's $r=0.852$, Adjusted $R^{2}=0.710$

\section{Biomass Burning Total Carbon $\left(\mathrm{TC}_{\mathrm{BB}}\right)$}

By using the $\alpha$ coefficient, determined by linear regression, and the individual levoglucosan concentration (see equation 5), it is possible to calculate $\mathrm{TC}_{\mathrm{BB}}$ for each sample (Table 1). $\mathrm{TC}_{\mathrm{BB}}$ values are thus derived from both a molecular tracer and $\mathrm{TC}_{\mathrm{NF}}$ values, which are themselves derived from ${ }^{14} \mathrm{C}$ analyses:

$$
T C_{B B}=\alpha \times \text { levo }
$$


Table 1: Results of TC fractions

\begin{tabular}{|c|c|c|c|c|c|c|c|c|}
\hline Date $\mathrm{dd} / \mathrm{mm} / \mathrm{yy}$ & $\mathrm{TC}_{\mathrm{F}}$ & $\pm \mathrm{TC}_{\mathrm{F}}$ & $\mathrm{TC}_{\mathrm{NF}}$ & $\pm \mathrm{TC}_{\mathrm{NF}}$ & $\mathrm{TC}_{\mathrm{BB}}$ & $\pm \mathrm{TC}_{\mathrm{BB}}$ & $\mathrm{TC}_{\mathrm{bio}}$ & $\pm \mathrm{TC}_{\text {bio }}$ \\
\hline $30 / 05 / 2012$ & 2.37 & 0.09 & 3.30 & 0.12 & 0.18 & 0.04 & 3.11 & 0.21 \\
\hline 13/10/2012 & 0.98 & 0.09 & 5.17 & 0.18 & 3.45 & 0.80 & 1.52 & 0.87 \\
\hline 20/11/2012 & 3.66 & 0.32 & 20.63 & 0.66 & 18.92 & 4.38 & 0.61 & 4.69 \\
\hline 22/11/2012 & 3.76 & 0.30 & 18.70 & 0.60 & 12.44 & 2.88 & 5.54 & 3.12 \\
\hline $08 / 01 / 2013$ & 1.79 & 0.26 & 17.59 & 0.57 & 14.00 & 3.24 & 2.78 & 3.48 \\
\hline $09 / 01 / 2013$ & 2.47 & 0.31 & 20.41 & 0.66 & 16.79 & 3.88 & 2.65 & 4.17 \\
\hline $10 / 01 / 2013$ & 1.25 & 0.17 & 11.36 & 0.37 & 4.41 & 1.02 & 6.69 & 1.17 \\
\hline 18/01/2013 & 1.44 & 0.23 & 14.27 & 0.47 & 4.94 & 1.14 & 9.04 & 1.33 \\
\hline 27/01/2013 & 1.88 & 0.23 & 15.29 & 0.50 & 6.65 & 1.54 & 8.25 & 1.72 \\
\hline $30 / 01 / 2013$ & 2.07 & 0.15 & 10.53 & 0.29 & 3.70 & 0.86 & 6.61 & 0.98 \\
\hline $23 / 02 / 2013$ & 2.03 & 0.11 & 5.98 & 0.20 & 4.72 & 1.09 & 0.99 & 1.18 \\
\hline $24 / 02 / 2013$ & 1.96 & 0.10 & 5.04 & 0.17 & 3.48 & 0.81 & 1.35 & 0.88 \\
\hline $25 / 02 / 2013$ & 1.79 & 0.11 & 6.45 & 0.22 & 6.08 & 1.41 & 0.03 & 1.51 \\
\hline $26 / 02 / 2013$ & 2.25 & 0.18 & 11.00 & 0.36 & 3.94 & 0.91 & 6.84 & 1.06 \\
\hline $27 / 02 / 2013$ & 2.08 & 0.20 & 12.58 & 0.41 & 6.28 & 1.45 & 5.93 & 1.61 \\
\hline $01 / 03 / 2013$ & 1.83 & 0.15 & 8.78 & 0.29 & 5.04 & 1.17 & 3.45 & 1.28 \\
\hline $02 / 03 / 2013$ & 1.48 & 0.12 & 6.82 & 0.23 & 4.00 & 0.93 & 2.59 & 1.02 \\
\hline $03 / 03 / 2013$ & 3.91 & 0.23 & 12.46 & 0.41 & 8.26 & 1.91 & 3.72 & 2.07 \\
\hline $04 / 03 / 2013$ & 1.83 & 0.10 & 6.45 & 0.18 & 3.34 & 0.77 & 2.92 & 0.85 \\
\hline $09 / 03 / 2013$ & 2.07 & 0.11 & 5.45 & 0.19 & 5.15 & 1.19 & 0.00 & 1.28 \\
\hline $11 / 03 / 2013$ & 1.38 & 0.11 & 6.35 & 0.21 & 6.53 & 1.51 & 0.00 & 1.62 \\
\hline $13 / 07 / 2013$ & 1.98 & 0.08 & 2.74 & 0.10 & 0.04 & 0.01 & 2.69 & 0.19 \\
\hline $14 / 07 / 2013$ & 1.32 & 0.07 & 3.40 & 0.12 & 0.12 & 0.03 & 3.26 & 0.21 \\
\hline $23 / 07 / 2013$ & 1.91 & 0.07 & 2.32 & 0.07 & 0.03 & 0.01 & 2.29 & 0.16 \\
\hline $24 / 07 / 2013$ & 2.08 & 0.08 & 2.57 & 0.10 & 0.09 & 0.02 & 2.48 & 0.18 \\
\hline $16 / 08 / 2013$ & 1.54 & 0.07 & 1.96 & 0.08 & 0.08 & 0.02 & 1.88 & 0.16 \\
\hline 18/08/2013 & 1.33 & 0.07 & 2.93 & 0.11 & 0.16 & 0.04 & 2.77 & 0.20 \\
\hline $22 / 08 / 2013$ & 2.01 & 0.08 & 1.95 & 0.08 & 0.03 & 0.01 & 1.92 & 0.16 \\
\hline 23/08/2013 & 1.63 & 0.07 & 1.69 & 0.07 & 0.06 & 0.01 & 1.63 & 0.14 \\
\hline $30 / 08 / 2013$ & 1.78 & 0.08 & 3.04 & 0.11 & 0.34 & 0.08 & 2.68 & 0.21 \\
\hline
\end{tabular}

\section{Biogenic Total Carbon $\left(\mathrm{TC}_{\mathrm{bio}}\right)$}

The biogenic fraction of non-fossil carbon must be distinguished from the biomass burning fraction. The biogenic fraction has a $\mathrm{F}^{14} \mathrm{C}$ that should be close to the atmospheric $\mathrm{F}^{14} \mathrm{C}$ at the time of emission, which corresponds to the time of sample collection. By contrast, biomass burning is mainly based on wood that grew over a few decades, a timespan characterized by a gradual $\mathrm{F}^{14} \mathrm{C}$ decrease in the atmosphere since the thermonuclear bomb tests of the early 1960s. This implies that wood carbon has a mean $\mathrm{F}^{14} \mathrm{C}$ slightly higher than that of the atmosphere at the time of aerosol sampling. We have adopted the average $\mathrm{F}^{14} \mathrm{C}_{\mathrm{BB}}$ of 1.10 proposed by (Lewis et al., 2004; Szidat et al., 2006), based on atmospheric ${ }^{14} \mathrm{C}$ evolution and a tree growth model. To quantify the biogenic fraction of $\mathrm{TC}_{\mathrm{NF}}$, the following mass balance equation is used:

$$
\begin{gathered}
T C \times F^{14} C_{S}=T C_{B B} \times F^{14} C_{B B}+T C_{\text {bio }} \times F^{14} C_{\text {bio }}+T C_{F} \times F^{14} C_{F} \\
=T C_{B B} \times F^{14} C_{B B}+T C_{\text {bio }} \times F^{14} C_{\text {bio }}
\end{gathered}
$$

- TC, carbon concentration determined with the GIS $\left[\mu \mathrm{g} \cdot \mathrm{m}^{-3}\right]$,

- $\quad \mathrm{F}^{14} \mathrm{C}_{\mathrm{S}}$ measured in the sample, 
- $\quad \mathrm{TC}_{\mathrm{BB}}$, carbon concentration from biomass burning (based on the levoglucosan measurement and determination of $\alpha)\left[\mu \mathrm{g} \cdot \mathrm{m}^{-3}\right]$,

- $\quad \mathrm{F}^{14} \mathrm{C}_{\mathrm{BB}}$, modern fraction of 1.10 assumed for the wood used in biomass burning,

- $\quad \mathrm{TC}_{\text {bio, }}$, carbon concentration from biogenic emissions $\left[\mu \mathrm{g} \cdot \mathrm{m}^{-3}\right]$,

- $\quad \mathrm{F}^{14} \mathrm{C}_{\mathrm{bio}}$, modern fraction of 1.04 for biogenic emissions,

- $\quad \mathrm{TC}_{\mathrm{F}}$, carbon concentration from fossil sources $\left[\mu \mathrm{g} \cdot \mathrm{m}^{-3}\right]$,

- $\quad \mathrm{F}^{14} \mathrm{C}_{\mathrm{F}}$, modern fraction of 0 for the fossil emissions devoid of ${ }^{14} \mathrm{C}$.

From equation 6 , it is possible to derive $\mathrm{TC}_{\mathrm{bio}}$ as follows:

$$
T C_{\text {bio }}=\frac{T C \times F^{14} C_{S}-T C_{B B} \times F^{14} C_{B B}}{F^{14} C_{\text {bio }}}=\frac{T C \times F^{14} C_{S}-\alpha \times \text { levo } \times F^{14} C_{B B}}{F^{14} C_{\text {bio }}}
$$

As in previous equations, the different origins of factors are distinguished by color. Terms in purple represent experimental results on individual samples. The term in green originates from correlation between experimental data; terms in blue stand for values from the literature. $\mathrm{TC}_{\text {bio }}$ results are listed in Table 1 . The mean winter concentration of $\mathrm{TC}_{\text {bio }}$ is $4.0 \mu \mathrm{g} \mathrm{m}^{-3}\left(\mathrm{SD}=2.9 \mu \mathrm{g} \mathrm{m}^{-3}, \mathrm{~N}=20\right)$, which is compatible with the $\beta$ value of $2.5 \pm 1.3$ $\mu \mathrm{g} \mathrm{m}^{-3}$ determined in Figure 3.

It should be noted that the $\mathrm{f}_{\mathrm{NF}}$,ref value used to determine $\mathrm{f}_{\mathrm{NF}}$, and therefore $\mathrm{TC}_{\mathrm{NF}}$ and $\mathrm{TC}_{\mathrm{F}}$, is set to the atmospheric level $\left(1.04 \mathrm{~F}^{14} \mathrm{C}\right)$, as we assumed the non-fossil source to be purely biogenic. However, the non-fossil carbon is composed of biogenic and biomass burning fractions, which differ slightly in their ${ }^{14} \mathrm{C} /{ }^{12} \mathrm{C}$ ratios. Ideally,

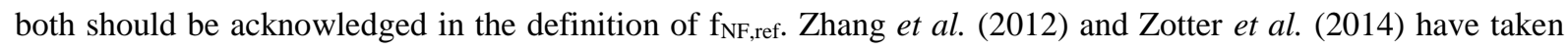
into account both $\mathrm{F}^{14} \mathrm{C}_{\text {bio }}$ and $\mathrm{F}^{14} \mathrm{C}_{\mathrm{BB}}$ in $\mathrm{f}_{\mathrm{NF}}$, by assuming their respective contributions. In Bonvalot et al. (2016), we set $f_{N F \text {,ref }}=F^{14} C_{\text {bio }}=1.04$ for summer samples but $f_{N F \text {,ref }}=F^{14} C_{B B}=1.10$ for winter samples because the levoglucosan winter levels were very high (mean value around $3 \mu \mathrm{g} . \mathrm{m}^{-3}$, and up to $8.5 \mu \mathrm{g} \cdot \mathrm{m}^{-3}$ ) and the $\beta$ value was indistinguishable, indicating negligible biogenic emissions during winter in these valleys.

Fos-sur-Mer can be viewed as an intermediate case because levoglucosan levels are lower and biogenic emissions are still present in winter (elevated $\mathrm{TC}_{\text {bio }}$ and $\beta$ values). It is thus difficult to make a priori assumptions about the $\mathrm{TC}_{\mathrm{bio}} / \mathrm{TC}_{\mathrm{NF}}$ ratio before the calculation. Nevertheless, the above determinations allow the a posteriori calculation of a more accurate $\mathrm{f}_{\mathrm{NF} \text {,ref }}$ value in winter: 1.08 , which is close to the 1.04 assumed in the calculation. Using the new $\mathrm{f}_{\mathrm{NF} \text {,ref }}$ value would change the $\mathrm{TC}_{\mathrm{NF}}$ and $\mathrm{TC}_{\mathrm{F}}$ by only $4 \%$, which is small compared to other measurement uncertainties.

\subsubsection{Organic carbon (OC) Elemental Carbon $(E C)$ source apportionment}

The relative contributions of EC and OC to the TC fraction are estimated following the same approach as (Salma et al., 2017), which is similar to those proposed by (Gelencsér et al., 2007) and (Gilardoni et al., 2011). The measurements of radiocarbon and levoglucosan are used together with the EC/TC ratio determined by thermaloptical analysis (ref). As a necessary complement in the calculation, we use a constant value for the $\mathrm{OC}_{\mathrm{BB}} / \operatorname{levoglucosan}$ as given by the literature ((Salma et al., 2017)). Calculation results for all samples are listed in Table 2 . 


\section{Elemental and organic fractions of the non-fossil carbon}

$\mathrm{TC}_{\mathrm{BB}}$ is composed of $\mathrm{EC}_{\mathrm{BB}}$ and $\mathrm{OC}_{\mathrm{BB}}$ which can be estimated using the partitioning factor $\mathrm{D}_{\mathrm{BB}}$, as defined below:

$$
\begin{gathered}
D_{B B}=\frac{\left(O C_{B B} /_{\text {levo }}\right) \times(E C / O C)_{B B}}{\alpha} \\
E C_{B B}=D_{B B} \times T C_{B B} \\
O C_{B B}=T C_{B B}-E C_{B B}
\end{gathered}
$$

The term in green originates from the correlation between experimental data; terms in blue stand for values from the literature.

- $\quad \alpha$, slope determined by linear regression between the measured levo and $\mathrm{TC}_{\mathrm{NF}}$ (see Figure 3),

- $\quad \mathrm{OC}_{\mathrm{BB}} /$ levo ratio of $5.59 \pm 1.68$, following work by (Salma et al., 2017). This value is compatible with a variety of wood types used in Austria (Schmidl et al., 2008).

- $\quad(\mathrm{EC} / \mathrm{OC})_{\mathrm{BB}}$ ratio of $0.17 \pm 0.009$ following work by (Salma et al., 2017), which is compatible with values of $0.16 \pm 0.01$ and $0.18 \pm 0.01$, as used by (Szidat et al., 2006) and (Bernardoni et al., 2013), respectively.

\section{- The biogenic organic carbon $\left(\mathrm{OC}_{\text {bio }}\right)$}

The $\mathrm{OC}_{\mathrm{bio}}$ fraction originates from vegetal emissions, with no combustion process. Therefore, $\mathrm{OC}_{\mathrm{bio}}$ corresponds to $\mathrm{TC}_{\mathrm{bio}}$ (i.e. $\mathrm{EC}_{\mathrm{bio}}=0$ ). $\mathrm{OC}_{\mathrm{bio}}$ is partly composed of secondary organic aerosols (SOAs), which are of mixed origin from fossil and non-fossil carbon fractions. SOAs are formed in the atmosphere by the transfer to the particle phase of VOCs (Volatile Organic Compounds) oxidized in the gas phase by atmospheric oxidant species (notably $\mathrm{OH}, \mathrm{O}_{3}$ ). Biogenic gaseous emissions consist mostly of isoprene, monoterpenes and sesquiterpenes, which are considered as the most important biogenic SOA precursors (Hallquist et al., 2009; Kanakidou et al., 2005).

\section{- The elemental and organic fractions of fossil carbon $\left(\mathrm{EC}_{\mathrm{F}}\right.$ and $\left.\mathrm{OC}_{\mathrm{F}}\right)$}

$\mathrm{TC}_{\mathrm{F}}$ is composed of $\mathrm{EC}_{\mathrm{F}}$ and $\mathrm{OC}_{\mathrm{F}}$, which can be estimated using a partitioning factor $\mathrm{D}_{\mathrm{F}}$, as defined below:

$$
D_{F}=\frac{(E C / T C)-\frac{E C_{B B}}{T C}}{1-f_{N F}}
$$

Purple represents experimental results on individual samples. The term in black originates from a previous calculation (equation 9).

- $\quad(\mathrm{EC} / \mathrm{TC})$ ratio as measured with the Sunset thermal-optical measurements,

- $\quad \mathrm{EC}_{\mathrm{BB}}$ calculated previously $\left[\mu \mathrm{g} \cdot \mathrm{m}^{-3}\right]$, 
- $\quad$ TC measured with the GIS during the ${ }^{14} \mathrm{C}$ analysis $\left[\mu \mathrm{g} \mathrm{m}^{-3}\right]$,

- $\quad \mathrm{f}_{\mathrm{NF}}$ deduced from ${ }^{14} \mathrm{C}$ measurements.

$$
\begin{gathered}
E C_{F}=D_{F} \times T C_{F} \\
O C_{F}=T C_{F}-E C_{F}
\end{gathered}
$$

The $\mathrm{OC}_{\mathrm{F}}$ fraction is composed of both primary $\left(\mathrm{POC}_{\mathrm{F}}\right)$ and secondary organic aerosols (SOC $)$. Fossil SOAs are formed by oxidation and condensation of exhaust gases, and can represent an important part of total SOAs (Huang et al., 2014).

\subsection{Apportionment results for Fos-sur-Mer and interpretation}

a)

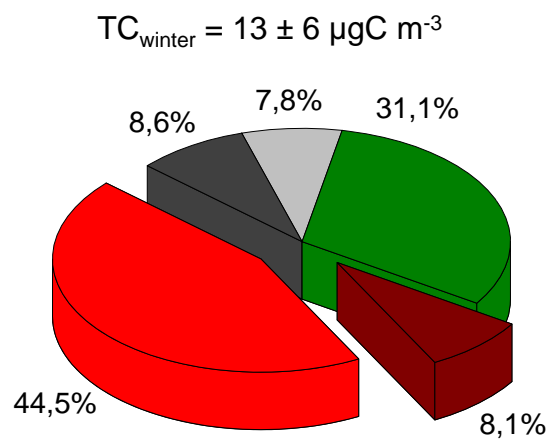

b)

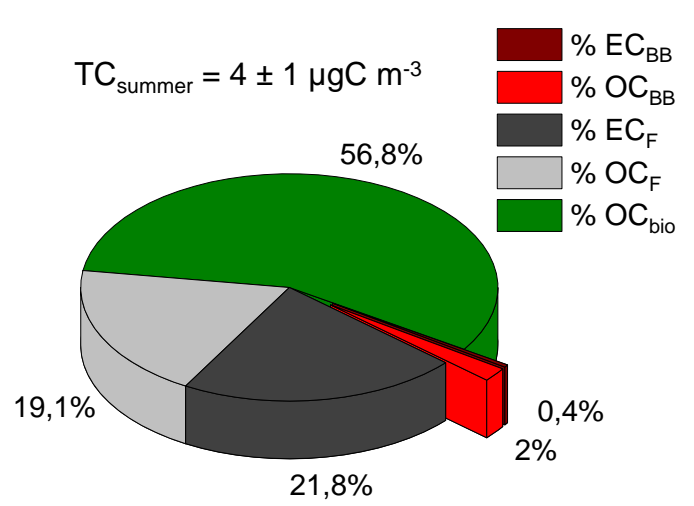

Figure 4 : Proportional contributions to carbonaceous aerosols for fall/winter 2012-13 (a) and summer 2013 (b)

Figure 4 shows the contributions of each carbonaceous fraction for the $\mathrm{PM}_{2.5}$ samples from fall/winter and from summer in Fos-sur-Mer, respectively. For fall and winter, the major contributor to the carbonaceous particles is biomass burning $(55 \%)$, whereas $\mathrm{OC}_{\text {bio }}$ represents $56 \%$ of the total carbon during summer. During the cold season, $\mathrm{OC}_{\mathrm{bio}}$ still represents more than a quarter of the total carbon; which can partly be linked to secondary aerosols from biomass burning emissions ( $\mathrm{SOA}_{\mathrm{BB}}$ ) (Bertrand et al., 2018). $\mathrm{EC}_{\mathrm{F}}$ and $\mathrm{OC}_{\mathrm{F}}$ contribute about $8 \%$ and $10 \%$, respectively. The influence of biomass burning during summer is very low with a total of $3 \%(1 \%$ from $\mathrm{EC}_{\mathrm{BB}}$ and $2 \%$ from $\left.\mathrm{OC}_{\mathrm{BB}}\right)$ and the fossil source represents about $41 \%$ of the carbonaceous aerosols $\left(\mathrm{EC}_{\mathrm{F}} 22 \%\right.$ and $\left.19 \% \mathrm{OC}_{\mathrm{F}}\right)$. Hence, the relative proportions vary significantly with the season, with an important influence of biomass burning for the cold period.

It is interesting to compare the results obtained for Fos-sur-Mer with those available for other cities from different regions:

In Barcelona (Spain) the proportion of $\mathrm{OC}_{\mathrm{BB}}$ remains constant on a yearly basis; for winter $\mathrm{OC}_{\mathrm{BB}}$ represents $35 \%$ of $\mathrm{OC}_{\mathrm{NF}}$ and $33 \%$ in summer which correspond to 17-21\% of the total OC (Minguillón et al., 2011). In Marseilles, the main contribution to OA (Organic Aerosol) are biomass burning (BB) during winter (48\%) and OOA (Oxygenated Organic Aerosol, i.e. aged aerosol directly associated to SOA) during summer (63\%) (Bozzetti et al., 2017). 
For Zürich (Switzerland), very similar relative contributions are obtained in summer (Szidat et al., 2006), but the winter distribution shows less contribution from biomass burning in Zürich than in Fos-sur-Mer. Similar to Fos-sur-Mer, the summer PM in Göteborg (Sweden) is mainly composed of $\mathrm{OC}_{\text {bio }}(44 \%), \mathrm{EC}_{\mathrm{F}}$ and $\mathrm{OC}_{\mathrm{F}}(15 \%$ and $31 \%$, respectively), whereas the relative influence of biomass burning remains moderate in winter (Szidat et al., 2009), thus lower than in Fos-sur-Mer. This kind of seasonal variation was not detected in the urban background of a bigger city, Birmingham (UK), where the influence of biomass burning remains low and constant throughout the year ( $2 \%$ and $10 \%$ for $\mathrm{EC}_{\mathrm{BB}}$ and $\mathrm{OC}_{\mathrm{BB}}$, respectively), the main contributor being the fossil source (Heal et al., 2011).

An examination of EC during fall/winter reveals that half of it comes from biomass burning emissions, while the remainder is from fossil fuel combustion. Such an important contribution of biomass burning in EC was not observed in Milan where about $85 \%$ of EC was shown to originate from fossil sources (Bernardoni et al., 2013). In Barcelona (Spain), also a Mediterranean city, EC is fossil for $87 \%$ in winter and $91 \%$ in winter (Minguillón et al., 2011). For Montseny, located at $50 \mathrm{~km}$ of Barcelona in a forested background, EC fossil percentage is smaller (66\% in winter and $79 \%$ in summer).By contrast to winter, most summer EC (98\%) originates from fossil sources because biomass burning is very much reduced during the hot season in Fos-sur-Mer.

The relative importance of biomass burning during winter could appear as surprising because Fos-sur-Mer is located in the south of France with relatively mild winters, even if frequent cold episodes are linked to strong northerly winds. Indeed, similar contributions of wood burning are typically observed for colder regions such as alpine valleys (Bonvalot et al., 2016; Zotter et al., 2014)or in the Czerch city of Mladá Boleslav (Hovorka et al., 2015). However, in these colder regions, wood is usually burnt in closed fireplaces and woodstoves, whereas green waste combustion and agricultural combustion may be more frequent in the south of France.

The city of Ispra in northern Italy bears some similarities with Fos-sur-Mer in terms of industries and traffic. As reported by (Gilardoni et al., 2011), the PM from Ispra presents similar seasonal patterns, with $12 \%$ of $\mathrm{EC}_{\mathrm{F}}$, $15 \%$ of $\mathrm{OC}_{\mathrm{F}}, 11 \%$ of $\mathrm{EC}_{\mathrm{BB}}, 53 \%$ of $\mathrm{OC}_{\mathrm{BB}}, 9 \%$ of $\mathrm{OC}_{\mathrm{bio}}$ in winter and $18 \%$ of $\mathrm{EC}_{\mathrm{F}}, 15 \%$ of $\mathrm{OC}_{\mathrm{F}}, 1 \%$ of $\mathrm{EC}_{\mathrm{BB}}, 8$ $\%$ of $\mathrm{OC}_{\mathrm{BB}}, 50 \%$ of $\mathrm{OC}_{\mathrm{bio}}$ in summer. Hence, the importance of biomass burning is even greater during winter in Ispra $(11+53=64 \%)$ than in Fos-sur-Mer $(44.5+8.1=52.6 \%)$. The difference may be due to slightly colder temperatures in Ispra than in Fos-sur-Mer (climatological DJF averages of $2.5{ }^{\circ} \mathrm{C}$ and $6.5{ }^{\circ} \mathrm{C}$, respectively, https://fr.climate-data.org/location/7679/). The absence of biomass burning during summer in Fos-sur-Mer, when the dry and hot weather frequently leads to wildfires in the region, confirms that the main source of $\mathrm{TC}_{\mathrm{BB}}$ is linked to wood burning for residential heating. During the fall, agricultural waste burning (notably from rice fields in the Camargue) may have also contributed to this fraction. 
a)

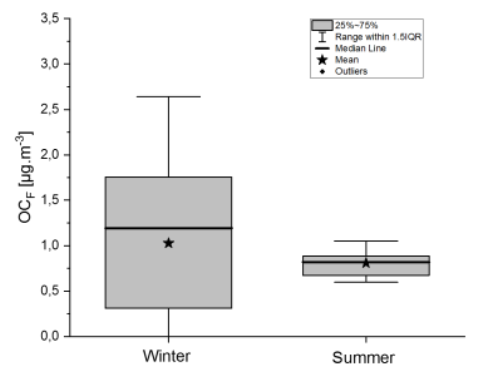

b)

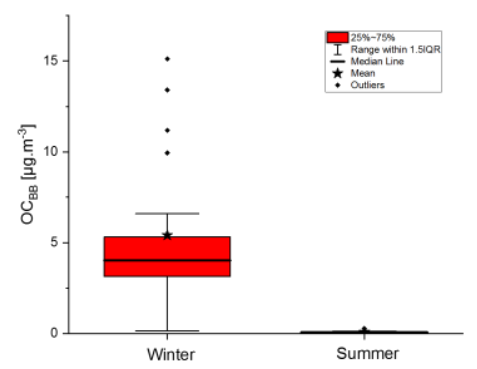

c)

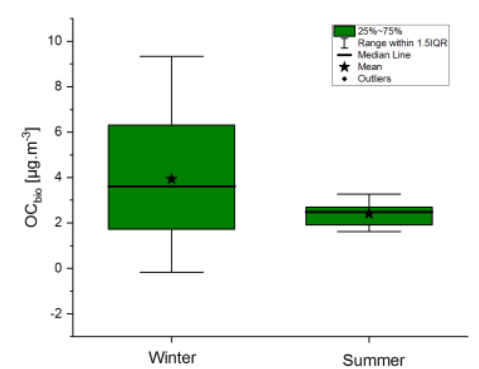

d)

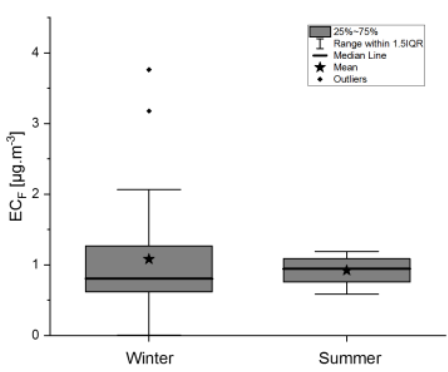

e)

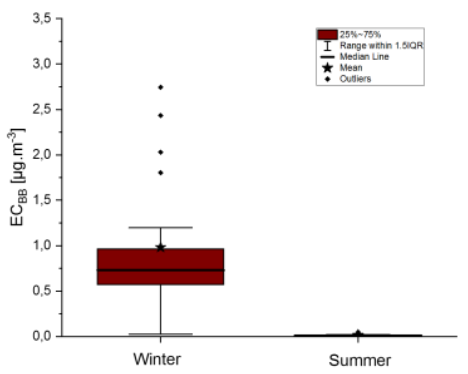

Figure 5 : Box plots of carbonaceous fractions a) $\left.\left.O C_{F} b\right) O C_{B B} c\right) O C_{B i o}$ d)EC $C_{F}$ e)EC $C_{B B}$

In addition to considering relative percent contributions, it is also important to compare absolute concentrations of the different fractions composing the aerosols. Figures 9 to 13 illustrate the stability of mean and median values of $\mathrm{OC}_{\mathrm{F}}, \mathrm{EC}_{\mathrm{F}}$ and $\mathrm{OC}_{\mathrm{bio}}$, suggesting that the emission levels for these fractions remain constant over the year. The stability of fossil carbon $\left(\mathrm{OC}_{\mathrm{F}}, \mathrm{EC}_{\mathrm{F}}\right)$ is compatible with the stability of the vehicular traffic throughout the year (ref.). By contrast, the biomass burning components $\left(\mathrm{OC}_{\mathrm{BB}}, \mathrm{EC}_{\mathrm{BB}}\right)$ are highly seasonal, as is to be expected from domestic heating.

The scatter observed for winter values of $\mathrm{OC}_{\mathrm{F}}, \mathrm{EC}_{\mathrm{F}}$ and $\mathrm{OC}_{\mathrm{bio}}$ is larger than for summer values. The same is true for the biomass burning fractions $\left(\mathrm{OC}_{\mathrm{BB}}\right.$ in Figure 10, $\mathrm{EC}_{\mathrm{BB}}$ in Figure 13, levoglucosan in Figure 3). This could be fortuitous and simply due to the difference in number of measurements for the two seasons $(\mathrm{N}=20$ and 9, for winter/fall and summer, respectively). An alternative explanation could be high frequency meteorological variations, notably the presence of the northerly wind that efficiently transports air masses towards the Mediterranean Sea.

The mean values of $\mathrm{TC}_{\text {bio }}\left(=\mathrm{OC}_{\mathrm{bio}}\right)$ remain stable during fall/winter and summer, respectively $4.0 \mu \mathrm{gC} \mathrm{m}^{-3}$ $(\mathrm{SD}=2.9, \mathrm{~N}=20)$ and $2.4 \mu \mathrm{gC} \mathrm{m}^{-3}(\mathrm{SD}=0.5, \mathrm{~N}=9)$, both equivalent to the $\beta$ factor $\left(2.5 \pm 1.3 \mu \mathrm{g} \mathrm{m}^{-3}\right)$. This fraction should be composed of both primary aerosols (cellulose, particulate abrasion produced from leaf surface, fungal spores, monosaccharides, and others) and secondary organic aerosols ( $\mathrm{SOA}_{\text {bio }}$ ). For example, (Bozzetti et al., 2016) have shown that for the rural site of Payerne (Switzerland), Primary Biologic Organic Aerosols (PBOAs) are comparable to the SOA contribution in the coarse organic matter (yearly average of $37 \%$, with $19 \%$ in winter and $60 \%$ in summer).

The stability of $\mathrm{TC}_{\text {bio }}$ may seem surprising because biological emissions by vegetation is enhanced during the warm season (Bozzetti et al., 2016, Bonvalot et al. 2016). On one hand, windy conditions during winter and 
fall may also favor the production and transport of primary particles. On the other hand, secondary particles originating from the aging of $\mathrm{BB}$ emissions may represent an important fraction of the $\mathrm{OC}_{\text {bio }}$ fraction. Bertrand et al. (2018) have shown the importance of $\mathrm{SOA}_{\mathrm{BB}}$ formation (up to 7 times the initial OA concentration after $6 \mathrm{~h}$ of photo chemical oxidation) and the influence of the aging onto the aerosol composition.

In order to distinguish SOAs and POAs, it is useful to compare $\mathrm{TC}_{\text {bio }}$ with molecular markers such as malic acid and DL-glyceric acid. Malic acid has been proposed as a late-stage product in the photooxydation process of fatty acids synthesized by plants (Hsieh et al., 2007). It can also originate from the oxidation of n-alkanes emitted by the vegetation (Claeys et al., 2004; Kawamura et al., 1996; Kawamura and Bikkina, 2016). It has been shown that DL-glyceric acid can be produced by the oxidation of diene compounds synthesized by vegetation (Angove et al., 2006). Figures 14 and 15 report significant correlations between $\mathrm{TC}_{\mathrm{bio}}$ and both organic acids during summer, thus confirming the importance of SOAs. This is in agreement with the conclusions made by El Haddad et al., (2013) who attributed the presence during summer in Marseille of OOAs (Oxygenated Organic Aerosols) commonly related to SOAs (Jimenez et al., 2009) - to non-fossil sources despite the strong industrial and urban sources.

However, both zero intercepts of the linear regressions are significantly different from zero $\left(1.7 \pm 0.3 \mu \mathrm{g} \mathrm{m}^{-}\right.$ ${ }^{3}$ in figure 14 and $2.0 \pm 0.2 \mu \mathrm{g} \mathrm{m}^{-3}$ in figure 15 ), which also points to the presence of POAs, amounting to about one third to one half of $\mathrm{TC}_{\text {bio. }}$. By contrast, malic acid levels are low in winter, and neither malic nor DL-glyceric acid is correlated with $\mathrm{TC}_{\text {bio. }}$. This is compatible with the hypothesis that $\mathrm{TC}_{\mathrm{bio}}$ is mainly linked to production and transport of POAs. Hence, the apparent stability of $\mathrm{TC}_{\text {bio }}$ regardless of season may be due to a strong seasonality of the SOA/POA ratio of emissions by vegetation. 

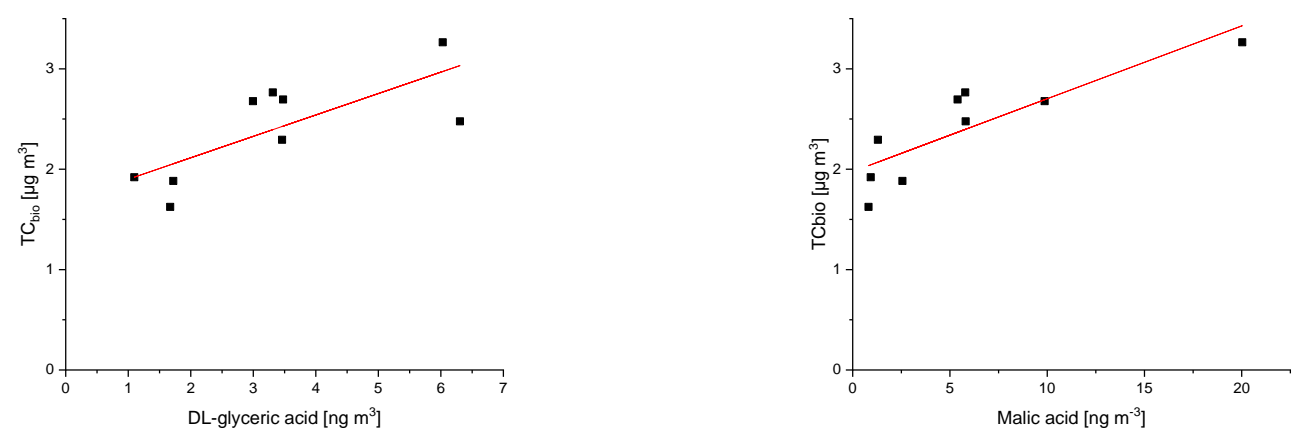

Figure 6: Correlation between $\mathrm{OC}_{\text {bio }}$ and (a) DL glyceric acid Pearson's $\mathrm{R}=\mathbf{0 . 7 4 9}$ (b) malic acid Pearson's $\mathrm{R}=\mathbf{0 . 8 5 3}$, for summer samples

Table 2: Results of EC-OC fractions

\begin{tabular}{|c|c|c|c|c|c|c|c|c|c|c|}
\hline $\begin{array}{c}\text { Date } \\
\mathrm{dd} / \mathrm{mm} / \mathrm{yy}\end{array}$ & $\mathrm{EC}_{\mathrm{F}}$ & $\pm \mathrm{EC}_{\mathrm{F}}$ & $\mathrm{OC}_{\mathrm{F}}$ & $\pm \mathrm{OC}_{\mathrm{F}}$ & $\mathrm{EC}_{\mathrm{BB}}$ & $\pm \mathrm{EC}_{\mathrm{BB}}$ & $\mathrm{OC}_{\mathrm{BB}}$ & $\pm \mathrm{OC}_{\mathrm{BB}}$ & $\mathrm{OC}_{\text {bio }}$ & $\pm \mathrm{OC}_{\mathrm{bio}}$ \\
\hline $30 / 05 / 2012$ & 0.62 & 0.15 & 1.75 & 0.14 & 0.03 & 0.02 & 0.15 & 0.04 & 3.11 & 0.21 \\
\hline $13 / 10 / 2012$ & 0.67 & 1.52 & 0.31 & 0.31 & 0.50 & 0.19 & 2.95 & 0.83 & 1.52 & 0.87 \\
\hline $20 / 11 / 2012$ & 3.18 & 8.75 & 0.48 & 1.61 & 2.74 & 1.05 & 16.18 & 4.55 & 0.61 & 4.69 \\
\hline $22 / 11 / 2012$ & 3.76 & 6.46 & 0.00 & 1.36 & 1.80 & 0.69 & 10.64 & 2.99 & 5.54 & 3.12 \\
\hline $08 / 01 / 2013$ & 1.03 & 9.30 & 0.76 & 0.99 & 2.03 & 0.78 & 11.97 & 3.36 & 2.78 & 3.48 \\
\hline $09 / 01 / 2013$ & 0.65 & 8.79 & 1.82 & 1.11 & 2.43 & 0.93 & 14.35 & 4.03 & 2.65 & 4.17 \\
\hline $10 / 01 / 2013$ & 1.24 & 3.94 & 0.01 & 0.50 & 0.64 & 0.25 & 3.77 & 1.06 & 6.69 & 1.17 \\
\hline $18 / 01 / 2013$ & 1.44 & 5.38 & 0.00 & 0.63 & 0.72 & 0.27 & 4.23 & 1.19 & 9.04 & 1.33 \\
\hline 27/01/2013 & 1.80 & 5.17 & 0.08 & 0.71 & 0.96 & 0.37 & 5.69 & 1.60 & 8.25 & 1.72 \\
\hline $30 / 01 / 2013$ & 2.07 & 3.07 & 0.00 & 0.64 & 0.54 & 0.21 & 3.16 & 0.89 & 6.61 & 0.98 \\
\hline 23/02/2013 & 0.15 & 0.87 & 1.88 & 0.32 & 0.68 & 0.26 & 4.03 & 1.13 & 0.99 & 1.18 \\
\hline $24 / 02 / 2013$ & 0.01 & 0.54 & 1.96 & 0.23 & 0.51 & 0.19 & 2.98 & 0.84 & 1.35 & 0.88 \\
\hline $25 / 02 / 2013$ & 0.01 & 1.32 & 1.78 & 0.38 & 0.88 & 0.34 & 5.19 & 1.46 & 0.03 & 1.51 \\
\hline $26 / 02 / 2013$ & 0.80 & 1.55 & 1.44 & 0.37 & 0.57 & 0.22 & 3.37 & 0.95 & 6.84 & 1.06 \\
\hline $27 / 02 / 2013$ & 0.65 & 2.62 & 1.43 & 0.48 & 0.91 & 0.35 & 5.37 & 1.51 & 5.93 & 1.61 \\
\hline $01 / 03 / 2013$ & 0.53 & 1.68 & 1.30 & 0.38 & 0.73 & 0.28 & 4.31 & 1.21 & 3.45 & 1.28 \\
\hline $02 / 03 / 2013$ & 0.17 & 1.17 & 1.31 & 0.28 & 0.58 & 0.22 & 3.42 & 0.96 & 2.59 & 1.02 \\
\hline $03 / 03 / 2013$ & 1.27 & 1.98 & 2.64 & 0.66 & 1.20 & 0.46 & 7.06 & 1.98 & 3.72 & 2.07 \\
\hline $04 / 03 / 2013$ & 1.02 & 1.15 & 0.81 & 0.34 & 0.48 & 0.19 & 2.86 & 0.80 & 2.92 & 0.85 \\
\hline $09 / 03 / 2013$ & 0.88 & 1.09 & 1.19 & 0.43 & 0.75 & 0.29 & 4.41 & 1.24 & 0.00 & 1.28 \\
\hline $11 / 03 / 2013$ & 0.77 & 2.22 & 0.61 & 0.50 & 0.95 & 0.36 & 5.59 & 1.57 & 0.00 & 1.62 \\
\hline $13 / 07 / 2013$ & 0.93 & 0.24 & 1.05 & 0.19 & 0.01 & 0.02 & 0.04 & 0.01 & 2.69 & 0.19 \\
\hline $14 / 07 / 2013$ & 0.58 & 0.27 & 0.74 & 0.13 & 0.02 & 0.02 & 0.11 & 0.03 & 3.26 & 0.21 \\
\hline $23 / 07 / 2013$ & 1.09 & 0.26 & 0.82 & 0.22 & 0.00 & 0.02 & 0.02 & 0.01 & 2.29 & 0.16 \\
\hline $24 / 07 / 2013$ & 1.19 & 0.29 & 0.89 & 0.25 & 0.01 & 0.02 & 0.08 & 0.02 & 2.48 & 0.18 \\
\hline $16 / 08 / 2013$ & 0.94 & 0.25 & 0.60 & 0.21 & 0.01 & 0.02 & 0.06 & 0.02 & 1.88 & 0.16 \\
\hline $18 / 08 / 2013$ & 0.66 & 0.27 & 0.67 & 0.14 & 0.02 & 0.02 & 0.14 & 0.04 & 2.77 & 0.20 \\
\hline $22 / 08 / 2013$ & 1.15 & 0.23 & 0.86 & 0.25 & 0.00 & 0.02 & 0.03 & 0.01 & 1.92 & 0.16 \\
\hline $23 / 08 / 2013$ & 1.00 & 0.22 & 0.63 & 0.22 & 0.01 & 0.02 & 0.05 & 0.01 & 1.63 & 0.14 \\
\hline $30 / 08 / 2013$ & 0.76 & 0.25 & 1.02 & 0.17 & 0.05 & 0.03 & 0.29 & 0.08 & 2.68 & 0.21 \\
\hline
\end{tabular}




\section{Conclusions}

Carbonaceous aerosols from the heavily industrialized Fos-sur-Mer region are apportioned using a multiproxy approach. Radiocarbon $\left({ }^{14} \mathrm{C}\right)$ analyses allow the distinction and quantification of fossil fuel combustion produced and non-fossil carbon from biomass burning and biogenic emissions. The different origins of fractions in $\mathrm{PM}_{2.5}$ samples are determined by using ${ }^{14} \mathrm{C}$ results combined with the EC/OC ratio, levoglucosan (biomass combustion proxy) and selected fatty acids (biogenic emission proxy).

Samples collected in the summer and fall/winter period of 2013 period indicate that carbonaceous material represents about $30 \%$ of the $\mathrm{PM}_{2.5}$ mass. Our multi-proxy approach provides information on the main sources of pollutants:

- A strong seasonal cycle is detected with a mean concentration three times larger in fall/winter than in summer. Combined ${ }^{14} \mathrm{C}$ and levoglucosan measurements allow to identify biomass burning for residential heating purposes during fall and winter as the main contributor $(\approx 83 \%$ of the non-fossil carbon, $\approx 53 \%$ of the total carbonaceous aerosols).

- For winter samples, $\mathrm{TC}_{\mathrm{NF}}$ concentrations are strongly correlated with methoxyphenol compounds (vaniline, acetovanillone and vanillic acid) which are BB tracers both primary and secondary emitted.

- The elemental carbon proportion (EC) varies strongly with the season. During summer, $98 \%$ of EC comes from fossil fuel sources (i.e. $\mathrm{EC}_{\mathrm{F}}$ ), whereas only $45 \%$ of $\mathrm{EC}$ is composed of $\mathrm{EC}_{\mathrm{F}}$ for fall/winter, which is due to a higher contribution from biomass burning.

- Overall, fossil carbons $\left(\mathrm{EC}_{\mathrm{F}}+\mathrm{OC}_{\mathrm{F}}\right)$ from industrial, shipping and vehicular sources are relatively higher during the summer, but their absolute concentration is stable across the seasons.

- A significant contribution of biogenic carbon $\left(\mathrm{TC}_{\mathrm{bio}}\right)$ is quantified for both summer and winter samples. Comparison with biogenic molecular proxies suggests that primary and secondary aerosols are quantitatively important. The absence of seasonality of $\mathrm{TC}_{\mathrm{bio}}$ may be due to variations of the relative proportions of primary and secondary organic aerosols, POAs being dominant in winter while SOAs represent up to a half of $\mathrm{TC}_{\text {bio }}$ in summer.

- When compared with other sites in Europe, our data enable the identification of specific aspects linked to the meteorology around Fos-sur-Mer, a region that is characterized by hot summers and mild but windy winters.

The scatter of concentrations observed during winter and fall will complicate the identification of short-lived emissions peaks linked to various industries in the Fos-Berre region. Nevertheless, our study provides important constraints on the pollution background in this populated region. Further work is planned to improve this apportionment, notably by performing ${ }^{14} \mathrm{C}$ measurements directly in the OC and EC sub-fractions (Dusek et al., 2014; Zhang et al., 2012; Zotter et al., 2014).

Acknowledgements: AixMICADAS was acquired and is operated in the framework of the EQUIPEX project ASTER-CEREGE (PI E. Bard) with additional matching funds from the Collège de France, which also supports the salaries of the authors from CEREGE.

\section{References}


Aiken, A. C., DeCarlo, P. F., Kroll, J. H., Worsnop, D. R., Huffman, J. A., Docherty, K. S., Ulbrich, I. M., Mohr, C., Kimmel, J. R., Sueper, D., Sun, Y., Zhang, Q., Trimborn, A., Northway, M., Ziemann, P. J., Canagaratna, M. R., Onasch, T. B., Alfarra, M. R., Prevot, A. S. H., Dommen, J., Duplissy, J., Metzger, A., Baltensperger, U. and Jimenez, J. L.: O/C and OM/OC Ratios of Primary, Secondary, and Ambient Organic Aerosols with High-Resolution Time-of-Flight Aerosol Mass Spectrometry, Environ. Sci. Technol., 42(12), 4478-4485, doi:10.1021/es703009q, 2008.

Angove, D. E., Fookes, C. J. R., Hynes, R. G., Walters, C. K. and Azzi, M.: The characterisation of secondary organic aerosol formed during the photodecomposition of 1,3-butadiene in air containing nitric oxide, Atmos. Environ., 40(24), 4597-4607, doi:10.1016/j.atmosenv.2006.03.046, 2006.

Bard, E., Tuna, T., Fagault, Y., Bonvalot, L., Wacker, L., Fahrni, S. and Synal, H.-A.: AixMICADAS, the accelerator mass spectrometer dedicated to $14 \mathrm{C}$ recently installed in Aix-en-Provence, France, Nucl. Instrum. Methods Phys. Res. Sect. B Beam Interact. Mater. At., 361, 80-86, doi:10.1016/j.nimb.2015.01.075, 2015.

Beekmann, M., Prévôt, A. S. H., Drewnick, F., Sciare, J., Pandis, S. N., Denier van der Gon, H. A. C., Crippa, M., Freutel, F., Poulain, L., Ghersi, V., Rodriguez, E., Beirle, S., Zotter, P., von der Weiden-Reinmüller, S.-L., Bressi, M., Fountoukis, C., Petetin, H., Szidat, S., Schneider, J., Rosso, A., El Haddad, I., Megaritis, A., Zhang, Q. J., Michoud, V., Slowik, J. G., Moukhtar, S., Kolmonen, P., Stohl, A., Eckhardt, S., Borbon, A., Gros, V., Marchand, N., Jaffrezo, J. L., Schwarzenboeck, A., Colomb, A., Wiedensohler, A., Borrmann, S., Lawrence, M., Baklanov, A. and Baltensperger, U.: In situ, satellite measurement and model evidence on the dominant regional contribution to fine particulate matter levels in the Paris megacity, Atmos Chem Phys, 15(16), 9577-9591, doi:10.5194/acp-15-9577-2015, 2015.

Bernardoni, V., Calzolai, G., Chiari, M., Fedi, M., Lucarelli, F., Nava, S., Piazzalunga, A., Riccobono, F., Taccetti, F., Valli, G. and Vecchi, R.: Radiocarbon analysis on organic and elemental carbon in aerosol samples and source apportionment at an urban site in Northern Italy, J. Aerosol Sci., 56, 88-99, doi:10.1016/j.jaerosci.2012.06.001, 2013.

Bertrand, A., Stefenelli, G., Jen, C. N., Pieber, S. M., Bruns, E. A., Ni, H., Temime-Roussel, B., Slowik, J. G., Goldstein, A. H., Haddad, I. E., Baltensperger, U., Prévôt, A. S. H., Wortham, H. and Marchand, N.: Evolution of the chemical fingerprint of biomass burning organic aerosol during aging, Atmospheric Chem. Phys., 18(10), 7607-7624, doi:https://doi.org/10.5194/acp-18-7607-2018, 2018.

Birch, M. E. and Cary, R. A.: Elemental Carbon-Based Method for Monitoring Occupational Exposures to Particulate Diesel Exhaust, Aerosol Sci. Technol., 25(3), 221-241, doi:10.1080/02786829608965393, 1996.

Bonvalot, L., Tuna, T., Fagault, Y., Jaffrezo, J.-L., Jacob, V., Chevrier, F. and Bard, E.: Estimating contributions from biomass burning, fossil fuel combustion, and biogenic carbon to carbonaceous aerosols in the Valley of Chamonix: a dual approach based on radiocarbon and levoglucosan, Atmos Chem Phys, 16(21), 13753-13772, doi:10.5194/acp-16-13753-2016, 2016.

Bozzetti, C., Daellenbach, K. R., Hueglin, C., Fermo, P., Sciare, J., Kasper-Giebl, A., Mazar, Y., Abbaszade, G., El Kazzi, M., Gonzalez, R., Shuster-Meiseles, T., Flasch, M., Wolf, R., Křepelová, A., Canonaco, F., Schnelle-Kreis, J., Slowik, J. G., Zimmermann, R., Rudich, Y., Baltensperger, U., El Haddad, I. and Prévôt, A. S. H.: Size-Resolved Identification, Characterization, and Quantification of Primary Biological Organic Aerosol at a European Rural Site, Environ. Sci. Technol., 50(7), 3425-3434, doi:10.1021/acs.est.5b05960, 2016.

Bozzetti, C., El Haddad, I., Salameh, D., Daellenbach, K. R., Fermo, P., Gonzalez, R., Minguillón, M. C., Iinuma, Y., Poulain, L., Elser, M., Müller, E., Slowik, J. G., Jaffrezo, J.-L., Baltensperger, U., Marchand, N. and Prévôt, A. S. H.: Organic aerosol source apportionment by offline-AMS over a full year in Marseille, Atmos Chem Phys, 17(13), 8247-8268, doi:10.5194/acp17-8247-2017, 2017.

Caseiro, A., Bauer, H., Schmidl, C., Pio, C. A. and Puxbaum, H.: Wood burning impact on PM10 in three Austrian regions, Atmos. Environ., 43(13), 2186-2195, doi:10.1016/j.atmosenv.2009.01.012, 2009.

Cavalli, F., Viana, M., Yttri, K. E., Genberg, J. and Putaud, J.-P.: Toward a standardised thermal-optical protocol for measuring atmospheric organic and elemental carbon: the EUSAAR protocol, Atmos Meas Tech, 3(1), 79-89, doi:10.5194/amt-3-79$2010,2010$.

Chung, S. H. and Seinfeld, J. H.: Global distribution and climate forcing of carbonaceous aerosols, J. Geophys. Res. Atmospheres, 107(D19), 4407, doi:10.1029/2001JD001397, 2002.

Claeys, M., Graham, B., Vas, G., Wang, W., Vermeylen, R., Pashynska, V., Cafmeyer, J., Guyon, P., Andreae, M. O., Artaxo, P. and Maenhaut, W.: Formation of Secondary Organic Aerosols Through Photooxidation of Isoprene, Science, 303(5661), 1173-1176, doi:10.1126/science.1092805, 2004. 
Crenn, V., Fronval, I., Petitprez, D. and Riffault, V.: Fine particles sampled at an urban background site and an industrialized coastal site in Northern France - Part 1: Seasonal variations and chemical characterization, Sci. Total Environ., 578(Supplement C), 203-218, doi:10.1016/j.scitotenv.2015.11.165, 2017.

Currie, L. A.: Evolution and multidisciplinary frontiers of 14C aerosol science, Radiocarbon, 42(1), 115-126, 2000.

Dron, J., Chamaret, P., Marchand, N., Temime-Roussel, B., Ravier, S., Sylvestre, A. and Wortham, H.: Variabilité physicochimique des épisodes de pollution atmosphérique à proximité de la zone industrialo-portuaire de Fos-sur-Mer., Pollut. Atmos., (233) [online] Available from: http://lodel.irevues.inist.fr/pollution-atmospherique/index.php?id=6081, https://doi.org/10.4267/pollutionatmospherique. 6081, 2017.

Dusek, U., Monaco, M., Prokopiou, M., Gongriep, F., Hitzenberger, R., Meijer, H. A. J. and Röckmann, T.: Evaluation of a two-step thermal method for separating organic and elemental carbon for radiocarbon analysis, Atmos Meas Tech, 7(7), 19431955, doi:10.5194/amt-7-1943-2014, 2014.

Dusek, U., Hitzenberger, R., Kasper-Giebl, A., Kistler, M., Meijer, H. A. J., Szidat, S., Wacker, L., Holzinger, R. and Röckmann, T.: Sources and formation mechanisms of carbonaceous aerosol at a regional background site in the Netherlands: insights from a year-long radiocarbon study, Atmos Chem Phys, 17(5), 3233-3251, doi:10.5194/acp-17-3233-2017, 2017.

El Haddad, I., Marchand, N., Dron, J., Temime-Roussel, B., Quivet, E., Wortham, H., Jaffrezo, J. L., Baduel, C., Voisin, D., Besombes, J. L. and Gille, G.: Comprehensive primary particulate organic characterization of vehicular exhaust emissions in France, Atmos. Environ., 43(39), 6190-6198, doi:10.1016/j.atmosenv.2009.09.001, 2009.

El Haddad, I., Marchand, N., Wortham, H., Piot, C., Besombes, J.-L., Cozic, J., Chauvel, C., Armengaud, A., Robin, D. and Jaffrezo, J.-L.: Primary sources of PM2.5 organic aerosol in an industrial Mediterranean city, Marseille, Atmos Chem Phys, 11(5), 2039-2058, doi:10.5194/acp-11-2039-2011, 2011.

El Haddad, I., D’Anna, B., Temime-Roussel, B., Nicolas, M., Boreave, A., Favez, O., Voisin, D., Sciare, J., George, C., Jaffrezo, J.-L., Wortham, H. and Marchand, N.: Towards a better understanding of the origins, chemical composition and aging of oxygenated organic aerosols: case study of a Mediterranean industrialized environment, Marseille, Atmos Chem Phys, 13(15), 7875-7894, doi:10.5194/acp-13-7875-2013, 2013.

Favez, O., Cachier, H., Sciare, J., Sarda-Estève, R. and Martinon, L.: Evidence for a significant contribution of wood burning aerosols to PM2.5 during the winter season in Paris, France, Atmos. Environ., 43(22-23), 3640-3644, doi:10.1016/j.atmosenv.2009.04.035, 2009.

Fuzzi, S., Baltensperger, U., Carslaw, K., Decesari, S., Denier van der Gon, H., Facchini, M. C., Fowler, D., Koren, I., Langford, B., Lohmann, U., Nemitz, E., Pandis, S., Riipinen, I., Rudich, Y., Schaap, M., Slowik, J. G., Spracklen, D. V., Vignati, E., Wild, M., Williams, M. and Gilardoni, S.: Particulate matter, air quality and climate: lessons learned and future needs, Atmos Chem Phys, 15(14), 8217-8299, doi:10.5194/acp-15-8217-2015, 2015.

Gelencsér, A.: Major carbonaceous particle types and their sources, in Carbonaceous Aerosol, Springer., 2004.

Gelencsér, A., May, B., Simpson, D., Sánchez-Ochoa, A., Kasper-Giebl, A., Puxbaum, H., Caseiro, A., Pio, C. and Legrand, M.: Source apportionment of PM2.5 organic aerosol over Europe: Primary/secondary, natural/anthropogenic, and fossil/biogenic origin, J. Geophys. Res. Atmospheres, 112(D23), D23S04, doi:10.1029/2006JD008094, 2007.

Gilardoni, S., Vignati, E., Cavalli, F., Putaud, J. P., Larsen, B. R., Karl, M., Stenström, K., Genberg, J., Henne, S. and Dentener, F.: Better constraints on sources of carbonaceous aerosols using a combined $14 \mathrm{C}$ - macro tracer analysis in a European rural background site, Atmos Chem Phys, 11(12), 5685-5700, doi:10.5194/acp-11-5685-2011, 2011.

Goix, S., Dron, J., Raucau, A. and Chamaret, P.: Lancement de l'étude de biosurveillance des populations exposées aux émissions atmosphériques à proximité de la zone industrialo-portuaire de Fos-sur-Mer (INDEX), Pollut. Atmos., 233 [online] Available from: http://lodel.irevues.inist.fr/pollution-atmospherique/index.php?id=5214, 2017.

Hallquist, M., Wenger, J. C., Baltensperger, U., Rudich, Y., Simpson, D., Claeys, M., Dommen, J., Donahue, N. M., George, C., Goldstein, A. H., Hamilton, J. F., Herrmann, H., Hoffmann, T., Iinuma, Y., Jang, M., Jenkin, M. E., Jimenez, J. L., KiendlerScharr, A., Maenhaut, W., McFiggans, G., Mentel, T. F., Monod, A., Prévôt, A. S. H., Seinfeld, J. H., Surratt, J. D., Szmigielski, R. and Wildt, J.: The formation, properties and impact of secondary organic aerosol: current and emerging issues, Atmos Chem Phys, 9(14), 5155-5236, doi:10.5194/acp-9-5155-2009, 2009.

Heal, M. R., Naysmith, P., Cook, G. T., Xu, S., Duran, T. R. and Harrison, R. M.: Application of 14C analyses to source apportionment of carbonaceous PM2.5 in the UK, Atmos. Environ., 45(14), 2341-2348, doi:10.1016/j.atmosenv.2011.02.029, 2011. 
Hennigan, C. J., Sullivan, A. P., Collett, J. L. and Robinson, A. L.: Levoglucosan stability in biomass burning particles exposed to hydroxyl radicals, Geophys. Res. Lett., 37(9), L09806, doi:10.1029/2010GL043088, 2010.

Hovorka, J., Pokorná, P., Hopke, P. K., Křumal, K., Mikuška, P. and Píšová, M.: Wood combustion, a dominant source of winter aerosol in residential district in proximity to a large automobile factory in Central Europe, Atmos. Environ., 113, 98107, doi:10.1016/j.atmosenv.2015.04.068, 2015.

Hsieh, L.-Y., Kuo, S.-C., Chen, C.-L. and Tsai, Y. I.: Origin of low-molecular-weight dicarboxylic acids and their concentration and size distribution variation in suburban aerosol, Atmos. Environ., 41(31), 6648-6661, doi:10.1016/j.atmosenv.2007.04.014, 2007.

Hua, Q., Barbetti, M. and Rakowski, A. Z.: Atmospheric Radiocarbon for the Period 1950-2010, Radiocarbon, 55(4), 20592072, doi:10.2458/azu_js_rc.v55i2.16177, 2013.

Huang, R.-J., Zhang, Y., Bozzetti, C., Ho, K.-F., Cao, J.-J., Han, Y., Daellenbach, K. R., Slowik, J. G., Platt, S. M., Canonaco, F., Zotter, P., Wolf, R., Pieber, S. M., Bruns, E. A., Crippa, M., Ciarelli, G., Piazzalunga, A., Schwikowski, M., Abbaszade, G., Schnelle-Kreis, J., Zimmermann, R., An, Z., Szidat, S., Baltensperger, U., Haddad, I. E. and Prévôt, A. S. H.: High secondary aerosol contribution to particulate pollution during haze events in China, Nature, 514(7521), 218-222, doi:10.1038/nature13774, 2014

Jaffrezo, J. L., Calas, N. and Bouchet, M.: Carboxylic acids measurements with ionic chromatography, Atmos. Environ., 32(14), 2705-2708, doi:10.1016/S1352-2310(98)00026-0, 1998.

Jedynska, A., Hoek, G., Wang, M., Eeftens, M., Cyrys, J., Beelen, R., Cirach, M., De Nazelle, A., Keuken, M., Visschedijk, A., Nystad, W., Akhlaghi, H. M., Meliefste, K., Nieuwenhuijsen, M., de Hoogh, K., Brunekreef, B. and Kooter, I. M.: Spatial variations of levoglucosan in four European study areas, Sci. Total Environ., 505, 1072-1081, doi:10.1016/j.scitotenv.2014.10.091, 2015.

Jimenez, J. L., Canagaratna, M. R., Donahue, N. M., Prevot, A. S. H., Zhang, Q., Kroll, J. H., DeCarlo, P. F., Allan, J. D., Coe, H., Ng, N. L., Aiken, A. C., Docherty, K. S., Ulbrich, I. M., Grieshop, A. P., Robinson, A. L., Duplissy, J., Smith, J. D., Wilson, K. R., Lanz, V. A., Hueglin, C., Sun, Y. L., Tian, J., Laaksonen, A., Raatikainen, T., Rautiainen, J., Vaattovaara, P., Ehn, M., Kulmala, M., Tomlinson, J. M., Collins, D. R., Cubison, M. J., E, Dunlea, J., Huffman, J. A., Onasch, T. B., Alfarra, M. R., Williams, P. I., Bower, K., Kondo, Y., Schneider, J., Drewnick, F., Borrmann, S., Weimer, S., Demerjian, K., Salcedo, D., Cottrell, L., Griffin, R., Takami, A., Miyoshi, T., Hatakeyama, S., Shimono, A., Sun, J. Y., Zhang, Y. M., Dzepina, K., Kimmel, J. R., Sueper, D., Jayne, J. T., Herndon, S. C., Trimborn, A. M., Williams, L. R., Wood, E. C., Middlebrook, A. M., Kolb, C. E., Baltensperger, U. and Worsnop, D. R.: Evolution of Organic Aerosols in the Atmosphere, Science, 326(5959), 1525-1529, doi:10.1126/science.1180353, 2009.

Jordan, T. B., Seen, A. J. and Jacobsen, G. E.: Levoglucosan as an atmospheric tracer for woodsmoke, Atmos. Environ., 40(27), 5316-5321, doi:10.1016/j.atmosenv.2006.03.023, 2006.

Kanakidou, M., Seinfeld, J. H., Pandis, S. N., Barnes, I., Dentener, F. J., Facchini, M. C., Van Dingenen, R., Ervens, B., Nenes, A., Nielsen, C. J., Swietlicki, E., Putaud, J. P., Balkanski, Y., Fuzzi, S., Horth, J., Moortgat, G. K., Winterhalter, R., Myhre, C. E. L., Tsigaridis, K., Vignati, E., Stephanou, E. G. and Wilson, J.: Organic aerosol and global climate modelling: a review, Atmos Chem Phys, 5(4), 1053-1123, doi:10.5194/acp-5-1053-2005, 2005.

Kawamura, K. and Bikkina, S.: A review of dicarboxylic acids and related compounds in atmospheric aerosols: Molecular distributions, sources and transformation, Atmospheric Res., 170, 140-160, doi:10.1016/j.atmosres.2015.11.018, 2016.

Kawamura, K., Seméré, R., Imai, Y., Fujii, Y. and Hayashi, M.: Water soluble dicarboxylic acids and related compounds in Antarctic aerosols, J. Geophys. Res. Atmospheres, 101(D13), 18721-18728, doi:10.1029/96JD01541, 1996.

Lelieveld, J., Evans, J. S., Fnais, M., Giannadaki, D. and Pozzer, A.: The contribution of outdoor air pollution sources to premature mortality on a global scale, Nature, 525(7569), 367-371, doi:10.1038/nature15371, 2015.

Levin, I., Naegler, T., Kromer, B., Diehl, M., Francey, R. J., Gomez-Pelaez, A. J., Steele, L. P., Wagenbach, D., Weller, R. and Worthy, D. E.: Observations and modelling of the global distribution and long-term trend of atmospheric ${ }^{14} \mathrm{CO}_{2}$, Tellus B, 62(1), 26-46, doi:10.1111/j.1600-0889.2009.00446.x, 2010.

Levin, I., Kromer, B. and Hammer, S.: Atmospheric $\Delta 14$ CO 2 trend in Western European background air from 2000 to 2012, Tellus B, 65(0), doi:10.3402/tellusb.v65i0.20092, 2013.

Lewis, C. W., Klouda, G. A. and Ellenson, W. D.: Radiocarbon measurement of the biogenic contribution to summertime PM2.5 ambient aerosol in Nashville, TN, Atmos. Environ., 38(35), 6053-6061, doi:10.1016/j.atmosenv.2004.06.011, 2004. 
Martinsson, J., Abdul Azeem, H., Sporre, M. K., Bergström, R., Ahlberg, E., Öström, E., Kristensson, A., Swietlicki, E. and Eriksson Stenström, K.: Carbonaceous aerosol source apportionment using the Aethalometer model - evaluation by radiocarbon and levoglucosan analysis at a rural background site in southern Sweden, Atmos Chem Phys, 17(6), 4265-4281, doi:10.5194/acp-17-4265-2017, 2017.

Minguillón, M. C., Perron, N., Querol, X., Szidat, S., Fahrni, S. M., Alastuey, A., Jimenez, J. L., Mohr, C., Ortega, A. M., Day, D. A., Lanz, V. A., Wacker, L., Reche, C., Cusack, M., Amato, F., Kiss, G., Hoffer, A., Decesari, S., Moretti, F., Hillamo, R., Teinilä, K., Seco, R., Peñuelas, J., Metzger, A., Schallhart, S., Müller, M., Hansel, A., Burkhart, J. F., Baltensperger, U. and Prévôt, A. S. H.: Fossil versus contemporary sources of fine elemental and organic carbonaceous particulate matter during the DAURE campaign in Northeast Spain, Atmos Chem Phys, 11(23), 12067-12084, doi:10.5194/acp-11-12067-2011, 2011.

Minoura, H., Morikawa, T., Mizohata, A. and Sakamoto, K.: Carbonaceous aerosol and its characteristics observed in Tokyo and south Kanto region, Atmos. Environ., 61(Supplement C), 605-613, doi:10.1016/j.atmosenv.2012.07.058, 2012.

Penner, J. E., Chuang, C. C. and Grant, K.: Climate forcing by carbonaceous and sulfate aerosols, Clim. Dyn., 14(12), 839851, doi:10.1007/s003820050259, 1998.

Pope, C. A. I. and Dockery, D. W.: Health Effects of Fine Particulate Air Pollution: Lines that Connect, J. Air Waste Manag. Assoc., 56(6), 709-742, doi:10.1080/10473289.2006.10464485, 2006.

Pöschl, U.: Atmospheric Aerosols: Composition, Transformation, Climate and Health Effects, Angew. Chem. Int. Ed., 44(46), 7520-7540, doi:10.1002/anie.200501122, 2005.

Putaud, J.-P., Raes, F., Van Dingenen, R., Brüggemann, E., Facchini, M.-C., Decesari, S., Fuzzi, S., Gehrig, R., Hüglin, C., Laj, P., Lorbeer, G., Maenhaut, W., Mihalopoulos, N., Müller, K., Querol, X., Rodriguez, S., Schneider, J., Spindler, G., Brink, H. ten, Tørseth, K. and Wiedensohler, A.: A European aerosol phenomenology-2: chemical characteristics of particulate matter at kerbside, urban, rural and background sites in Europe, Atmos. Environ., 38(16), 2579-2595, doi:10.1016/j.atmosenv.2004.01.041, 2004.

Putaud, J.-P., Van Dingenen, R., Alastuey, A., Bauer, H., Birmili, W., Cyrys, J., Flentje, H., Fuzzi, S., Gehrig, R., Hansson, H. C., Harrison, R. M., Herrmann, H., Hitzenberger, R., Hüglin, C., Jones, A. M., Kasper-Giebl, A., Kiss, G., Kousa, A., Kuhlbusch, T. A. J., Löschau, G., Maenhaut, W., Molnar, A., Moreno, T., Pekkanen, J., Perrino, C., Pitz, M., Puxbaum, H., Querol, X., Rodriguez, S., Salma, I., Schwarz, J., Smolik, J., Schneider, J., Spindler, G., ten Brink, H., Tursic, J., Viana, M., Wiedensohler, A. and Raes, F.: A European aerosol phenomenology - 3: Physical and chemical characteristics of particulate matter from 60 rural, urban, and kerbside sites across Europe, Atmos. Environ., 44(10), 1308-1320, doi:10.1016/j.atmosenv.2009.12.011, 2010.

Puxbaum, H., Caseiro, A., Sánchez-Ochoa, A., Kasper-Giebl, A., Claeys, M., Gelencsér, A., Legrand, M., Preunkert, S. and Pio, C.: Levoglucosan levels at background sites in Europe for assessing the impact of biomass combustion on the European aerosol background, J. Geophys. Res. Atmospheres, 112(D23), D23S05, doi:10.1029/2006JD008114, 2007.

Ramanathan, V., Crutzen, P. J., Kiehl, J. T. and Rosenfeld, D.: Aerosols, Climate, and the Hydrological Cycle, Science, 294(5549), 2119-2124, doi:10.1126/science.1064034, 2001a.

Ramanathan, V., Crutzen, P. J., Lelieveld, J., Mitra, A. P., Althausen, D., Anderson, J., Andreae, M. O., Cantrell, W., Cass, G. R., Chung, C. E., Clarke, A. D., Coakley, J. A., Collins, W. D., Conant, W. C., Dulac, F., Heintzenberg, J., Heymsfield, A. J., Holben, B., Howell, S., Hudson, J., Jayaraman, A., Kiehl, J. T., Krishnamurti, T. N., Lubin, D., McFarquhar, G., Novakov, T., Ogren, P. K., Podgorny, I. A., Prather, K., Priestley, K., Prospero, J. M., Quinn, P. K., Rajeev, K., Rasch, P., Rupert, S., Sadourny, R., Satheesh, S. K., Shaw, G. E., Sheridan, P. and Valero, F. P. J.: Indian Ocean Experiment: An integrated analysis of the climate forcing and effects of the great Indo-Asian haze, J. Geophys. Res., 106(D22), 28371-28398, $2001 \mathrm{~b}$.

Reimer, P. J., Brown, T. A. and Reimer, R. W.: Discussion: Reporting and Calibration of Post-Bomb 14C Data, Radiocarbon, 46(3), 1299-1304, doi:10.2458/azu_js_rc.46.4183, 2004.

Riffault, V., Arndt, J., Marris, H., Mbengue, S., Setyan, A., Alleman, L. Y., Deboudt, K., Flament, P., Augustin, P., Delbarre, H. and Wenger, J.: Fine and Ultrafine Particles in the Vicinity of Industrial Activities: A Review, Crit. Rev. Environ. Sci. Technol., 45(21), 2305-2356, doi:10.1080/10643389.2015.1025636, 2015.

Salameh, D., Detournay, A., Pey, J., Pérez, N., Liguori, F., Saraga, D., Bove, M. C., Brotto, P., Cassola, F., Massabò, D., Latella, A., Pillon, S., Formenton, G., Patti, S., Armengaud, A., Piga, D., Jaffrezo, J. L., Bartzis, J., Tolis, E., Prati, P., Querol, X., Wortham, H. and Marchand, N.: PM2.5 chemical composition in five European Mediterranean cities: A 1-year study, Atmospheric Res., 155, 102-117, doi:10.1016/j.atmosres.2014.12.001, 2015. 
Salma, I., Németh, Z., Weidinger, T., Maenhaut, W., Claeys, M., Molnár, M., Major, I., Ajtai, T., Utry, N. and Bozóki, Z.: Source apportionment of carbonaceous chemical species to fossil fuel combustion, biomass burning and biogenic emissions by a coupled radiocarbon-levoglucosan marker method, Atmos Chem Phys Discuss, 2017, 1-21, doi:10.5194/acp-2017-406, 2017.

Schauer, J. J., Kleeman, M. J., Cass, G. R. and Simoneit, B. R. T.: Measurement of Emissions from Air Pollution Sources. 3. C1-C29 Organic Compounds from Fireplace Combustion of Wood, Environ. Sci. Technol., 35(9), 1716-1728, doi:10.1021/es001331e, 2001

Schmidl, C., Marr, I. L., Caseiro, A., Kotianová, P., Berner, A., Bauer, H., Kasper-Giebl, A. and Puxbaum, H.: Chemical characterisation of fine particle emissions from wood stove combustion of common woods growing in mid-European Alpine regions, Atmos. Environ., 42(1), 126-141, doi:10.1016/j.atmosenv.2007.09.028, 2008.

Seinfeld, J. H. and Pandis, S. N.: Atmospheric trace constituents, in Atmospheric chemistry and physics -- From air pollution to climate change, p. 60, John Wiley \& Sons., 2006.

Simoneit, B. R. T.: Biomass burning - a review of organic tracers for smoke from incomplete combustion, Appl. Geochem., 17(3), 129-162, doi:10.1016/S0883-2927(01)00061-0, 2002.

Simoneit, B. R. T., Schauer, J. J., Nolte, C. G., Oros, D. R., Elias, V. O., Fraser, M. P., Rogge, W. F. and Cass, G. R.: Levoglucosan, a tracer for cellulose in biomass burning and atmospheric particles, Atmos. Environ., 33(2), 173-182, doi:10.1016/S1352-2310(98)00145-9, 1999.

Sylvestre, A., Mizzi, A., Mathiot, S., Masson, F., Jaffrezo, J. L., Dron, J., Mesbah, B., Wortham, H. and Marchand, N.: Comprehensive chemical characterization of industrial PM2.5 from steel industry activities, Atmos. Environ., 152, 180-190, doi:10.1016/j.atmosenv.2016.12.032, 2017.

Synal, H.-A., Stocker, M. and Suter, M.: MICADAS: A new compact radiocarbon AMS system, Nucl. Instrum. Methods Phys. Res. Sect. B Beam Interact. Mater. At., 259(1), 7-13, doi:10.1016/j.nimb.2007.01.138, 2007.

Szidat, S., Jenk, T. M., Synal, H.-A., Kalberer, M., Wacker, L., Hajdas, I., Kasper-Giebl, A. and Baltensperger, U.: Contributions of fossil fuel, biomass-burning, and biogenic emissions to carbonaceous aerosols in Zurich as traced by $14 \mathrm{C}$, J. Geophys. Res. Atmospheres, 111(D7), D07206, doi:10.1029/2005JD006590, 2006.

Szidat, S., Ruff, M., Perron, N., Wacker, L., Synal, H.-A., Hallquist, M., Shannigrahi, A. S., Yttri, K. E., Dye, C. and Simpson, D.: Fossil and non-fossil sources of organic carbon (OC) and elemental carbon (EC) in Göteborg, Sweden, Atmos Chem Phys, 9(5), 1521-1535, doi:10.5194/acp-9-1521-2009, 2009.

Titos, G., del Águila, A., Cazorla, A., Lyamani, H., Casquero-Vera, J. A., Colombi, C., Cuccia, E., Gianelle, V., Močnik, G., Alastuey, A., Olmo, F. J. and Alados-Arboledas, L.: Spatial and temporal variability of carbonaceous aerosols: Assessing the impact of biomass burning in the urban environment, Sci. Total Environ., 578, 613-625, doi:10.1016/j.scitotenv.2016.11.007, 2017.

Waked, A., Favez, O., Alleman, L. Y., Piot, C., Petit, J.-E., Delaunay, T., Verlinden, E., Golly, B., Besombes, J.-L., Jaffrezo, J.-L. and Leoz-Garziandia, E.: Source apportionment of PM10 in a north-western Europe regional urban background site (Lens, France) using positive matrix factorization and including primary biogenic emissions, Atmos Chem Phys, 14(7), 3325-3346, doi:10.5194/acp-14-3325-2014, 2014.

Yttri, K. E., Schnelle-Kreis, J., Maenhaut, W., Abbaszade, G., Alves, C., Bjerke, A., Bonnier, N., Bossi, R., Claeys, M., Dye, C., Evtyugina, M., García-Gacio, D., Hillamo, R., Hoffer, A., Hyder, M., Iinuma, Y., Jaffrezo, J.-L., Kasper-Giebl, A., Kiss, G., López-Mahia, P. L., Pio, C., Piot, C., Ramirez-Santa-Cruz, C., Sciare, J., Teinilä, K., Vermeylen, R., Vicente, A. and Zimmermann, R.: An intercomparison study of analytical methods used for quantification of levoglucosan in ambient aerosol filter samples, Atmos Meas Tech, 8(1), 125-147, doi:10.5194/amt-8-125-2015, 2015.

Zhang, T., Claeys, M., Cachier, H., Dong, S., Wang, W., Maenhaut, W. and Liu, X.: Identification and estimation of the biomass burning contribution to Beijing aerosol using levoglucosan as a molecular marker, Atmos. Environ., 42(29), 7013-7021, doi:10.1016/j.atmosenv.2008.04.050, 2008.

Zhang, Y. L., Perron, N., Ciobanu, V. G., Zotter, P., Minguillón, M. C., Wacker, L., Prévôt, A. S. H., Baltensperger, U. and Szidat, S.: On the isolation of OC and EC and the optimal strategy of radiocarbon-based source apportionment of carbonaceous aerosols, Atmos Chem Phys Discuss, 12(7), 17657-17702, doi:10.5194/acpd-12-17657-2012, 2012.

Zotter, P., Ciobanu, V. G., Zhang, Y. L., El-Haddad, I., Macchia, M., Daellenbach, K. R., Salazar, G. A., Huang, R.-J., Wacker, L., Hueglin, C., Piazzalunga, A., Fermo, P., Schwikowski, M., Baltensperger, U., Szidat, S. and Prévôt, A. S. H.: Radiocarbon analysis of elemental and organic carbon in Switzerland during winter-smog episodes from 2008 to 2012 - Part 1: Source apportionment and spatial variability, Atmos Chem Phys, 14(24), 13551-13570, doi:10.5194/acp-14-13551-2014, 2014. 
